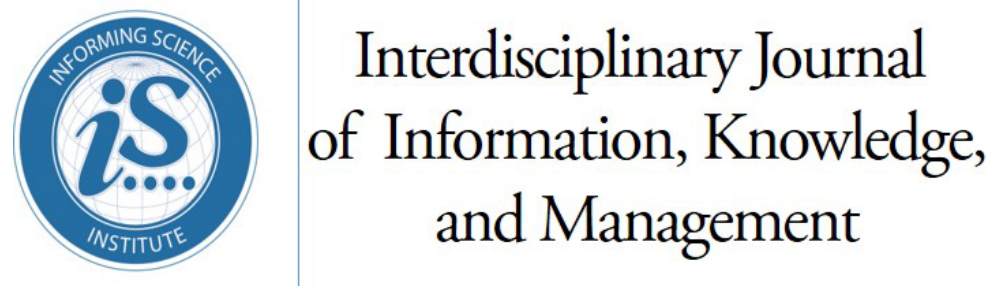

An Official Publication

of the Informing Science Institute

InformingScience.org

IJIKM.org

\title{
Volume 14, 2019 \\ THE ADOPTION OF CRM INITIATIVE AMONG Palestinian Enterprises: A Proposed FrameWork
}

Omar Hasan Salah*

Zawiyah Mohammad Yusof

Hazura Mohamed

* Corresponding author
Universiti Kebangsaan Malaysia, Omar_salah79@hotmail.com Bangi, Malaysia

Universiti Kebangsaan Malaysia, Bangi, Malaysia

Universiti Kebangsaan Malaysia, hazura.mohamed@ukm.edu.my Bangi, Malaysia

\section{ABSTRACT}

Aim/Purpose

This study aimed to examine the relationships among compatibility, relative advantage, complexity, IT Infrastructure, security, top Management Support, financial Support, information Policies, employee engagement, customer pressure, competitive pressure, information integrity, information sharing, attitude toward adopting technology factors, and CRM adoption

Background

Customer relationship management (CRM) refers to the use of the process, information, technology, and people for the management of the interactions between the organization and its customers. Therefore, there is a need for SMEs to implement CRM practices in their businesses for competitive advantage. However, in developing nations, the adoption rate of such practices remains low. This low rate may be attributed to the lack of important factors that guide CRM adoption, and as such, the present study attempts to investigate the factors affecting CRM adoption in Palestinian SMEs. This paper used the Diffusion of Innovation Theory (DOI), Resource-Based View (RBV), and Technology, Organization, and Environment Framework (TOE) framework to identify the determinant factors from the technological, organizational, environmental, and information culture perspectives.

Methodology

This study uses a quantitative approach to investigate the relationships between the variables. A questionnaire was designed to collect data from 420 SMEs in Palestine. 331 respondents completed and returned the survey. The Partial Least Square-Structural Equation Model (PLS-SEM) approach was used to assess both the measurement and structural models.

Accepting Editor Maureen Tanner | Received: July 7, 2019| Revised: September 12, October 8, 2019 | Accepted: October 19, 2019.

Cite as: Salah, O. H., Yusof, Z. M., \& Mohamed, H. (2019). The adoption of CRM initiative among Palestinian enterprises: A proposed framework. Interdisciplinary Journal of Information, Knowledge, and Management, 14, 367-403. https://doi.org/10.28945/4447

(CC BY-NC 4.0) This article is licensed to you under a Creative Commons Attribution-NonCommercial 4.0 International License. When you copy and redistribute this paper in full or in part, you need to provide proper attribution to it to ensure that others can later locate this work (and to ensure that others do not accuse you of plagiarism). You may (and we encourage you to) adapt, remix, transform, and build upon the material for any non-commercial purposes. This license does not permit you to use this material for commercial purposes. 
CRM Initiative among Palestinian Enterprises

Contribution This study contributes to both theory and practitioners by providing insights into factors that affect CRM adoption in Palestinian SMEs, which did not explore before. Future research suggestions are also provided.

Findings The results of the study prove that the adoption of CRM depends on compatibility (CMP), security (SEC), top management support (TMS), information policies (INP), financial resources (FR), employee engagement (EEN), competitive pressure (COP), customers pressure (CUP), attitude toward adopting technology (ATA), information integrity (INI), and information sharing (INS). Surprisingly, complexity (CMX), IT infrastructure (ITI), and relative advantage (RLA) do not play any role in CRM adoption in Palestine.

Recommendations for Practitioners

This study provides practitioners with the important factors for CRM adoption upon its successful implementation in the context of Palestinian SMEs.

Recommendations for Researchers

Our findings may be used to conduct further studies about compatibility, security, top management support, information policies, financial resources, employee engagement, competitive pressure, customers pressure, attitude toward adopting technology, information integrity, information sharing factors, and CRM adoption by using different countries, procedure, and context.

Impact on Society The proposed framework provides insights for SMEs which have significant effects for research and practice to help facilitate the adoption of CRM

Future Research The findings may also be compared to other studies conducted in different contexts and provide deeper insights into the influence of the examined contexts on the employees' intention toward CRM adoption in banking and universities. It would be fruitful to test whether the results hold true in developed and developing countries.

Keywords customer relationship management system, small and medium enterprise, CRM adoption, Palestine

\section{INTRODUCTION}

The world is experiencing an advanced stage of knowledge and scientific development that is characterized by tremendous rapid progress in all fields, especially the Information and Communication Technology (ICT). ICT provides small businesses with strategic advantages such as customer relationship management (CRM) systems, which could influence the achievement of goals to improve their competitive edge (Mohamad, Othman, Jabar, Majid, \& Kamarudin, 2014).

The CRM technology generally focuses on collecting, categorizing, and storing the required data of customers and developing customer-organization relationship using the general information on customer behavior (Teo, Devadoss, \& Pan, 2006). It is capable of integrating the marketing efforts of the organization and automating certain relationships between the organization and its customers (Harrigan, Ramsey, \& Ibbotson, 2012). The primary aim of using CRM is to improve customer relationships, which in turn, results in increased profitability, revenues, productivity, and customer satisfaction. Companies mainly adopt CRM as a business strategy to maximize their growth (Zeynep \& Toker, 2012).

Small and medium enterprises (SMEs) are categorized into classes based on some measurable quantitative indicators (Berisha \& Pula, 2015). These enterprises form the heart of entrepreneurial activity and innovation as they play a key role in the economies of emerging nations through the provision of employment opportunities and increasing the development of the economy (Salah, Yusof, \& Mohamed, 2018a). 
In the context of Palestine, the economy runs in an environment with internal and external risks challenges. World Bank (2018) indicates a high unemployment rate at $27 \%$ as of 2017 in the Palestinian territories. For example, in Gaza, the unemployment rate has reached $44 \%$, in comparison to the West Bank (18\%). Also, in 2017, only 41\% of employees between 15-29 years remained active in the labor market, indicating the employees' high pessimistic attitude towards employment opportunities (Baidoun, Lussier, Burbar, \& Awashra, 2018).

Nonetheless, the Palestinian Central Bureau of Statistics (PCBS) states that the ICT application adoption among Palestinians has experienced a gradual increase and is gaining increasing acknowledgment (The Portland Trust, 2012). ICT provides SMEs with strategic advantages such as customer relationship management (CRM) systems, which could influence the achievement of goals to improve their competitive edge (AlShawi, Missi, \& Irani, 2011). Palestine has a total of 14,359 enterprises where $99 \%$ of which belongs to the Palestinian SMEs and are categorized such that small enterprises have 5-19 employees and medium have 20-49 employees. These SMEs employ 82\% of the total workforce in the territory (Ramadan \& Ahmad, 2018a). Tax revenue collected from SMEs forms $99 \%$ of business taxpayers aids to fund the nation's growth and development (Alkhatib, Abdul-Jabbar, \& Marimuthu, 2018). Despite the small market Palestine has, SMEs remain as the backbone of economic growth and offer the most job opportunities (Atout, 2015) to the people with hope could help in eradicating poverty (Alfoqahaa, 2018).

A review of literature has indicated that there is a lack of studies dedicated to the business strategies adopted by SMEs (Ramadan \& Ahmad, 2018b) be it in general on specifically in Palestine. One way to leverage the capability of SMEs is to embark on the CRM initiative. Prior to the adoption of the initiative, factors that contribute to the success of adopting CRM must be made unpacked. Many studies have investigated a wide range of factors that may influence CRM adoption in SMEs in developed nations such as the U.S and the EU countries (Rahimi \& Kozak, 2017; Rodriguez, Peterson, \& Krishnan, 2018). Only a few studies have explored the adoption of CRM in developing countries generally (Jaber \& Simkin, 2017) and in Palestine in particular. This would finally help to improve the economic situation of Palestine. Thus, this study was to assess the relationships between CRM adoption and technological, organizational, environmental, and information culture factors to provide insights into the way the adoption of CRM is realized in Palestine

\section{RELATED WORKS ON CRM ADOPTION}

Customer relationship management (CRM) is a strategic tool for small and medium-sized enterprises (SMEs). It is evidenced that CRM practices have to be integrated into the day-to-day business process of such enterprises for competitive advantage (Mohamad et al., 2014). CRM adoption by SMEs would enable the provision of valuable information, enhanced knowledge, and relationships with its suppliers and customers, as evidenced in prior studies (Alshawi et al., 2011; P. Williams, Ashill, \& Naumann, 2017). However, for successful CRM adoption, it is important to shed light and identify the challenges that come with it, and some are linked to information culture, issues in the environment, and security of CRM (Awa, Ukoha, \& Emecheta, 2016; Iriana, Buttle, \& Ang, 2013; Osubor \& Chiemeke, 2015).

Past studies have found that SMEs can successfully adopt CRMs. Some studies focused on the related activities in the field of CRM, like selling and handling customer orders as well as the factors affecting the company's structure. Many factors are being studied by scholars, such as the barriers of technology adoption and use (AlMabhouh \& Alzaza, 2015); factors that contribute to the implementation of CRM like trust, knowledge management, data quality, and CRM facilitating factors (P. Williams et al., 2017).

Other studies have reported the capability of CRM technology in integrating the company's marketing efforts and automating certain relationships between the organization and its customers (Harrigan et al., 2012). CRM system makes use of technology for coordinating and integrating aspects of 
the company, including marketing, sales, outstanding orders, customer-organization interactions, service and repair, unresolved issues, and customer service. It allows system integration from the bottom to the top, entailing supply chain, internal and external customers, labor requirements, and stakeholders. Therefore, the CRM system has to be developed based on customer requirements from the onset (Salah et al., 2018a).

The majority of studies in this field concentrate on developed nations such as the US (Rodriguez et al., 2018) and EU countries (Rahimi \& Kozak, 2017). These findings, however, cannot be compared or applicable to developing countries owing to the differences based on the CRM practices and the challenges faced in its implementation (Jaber \& Simkin, 2017; Ramaseshan, Bejou, Jain, Mason, \& Pancras, 2006). Some researchers like AbuShanab, Pearson, and Setterstrom (2010) revealed that most technology adoption theories and models fail to focus on developing nations. In the context of Palestine, there is no one single accepted theory and models that may be applied to small businesses (Baidoun et al., 2018), which, in effect, necessitates studies to do so and proposed framework would assist SMEs in Palestine to embark on the appropriate and complete CRM initiative.

Also, CRM adoption rate among SMEs in developing nations remains low as the initiative is still at infancy (Alkhazali \& Hassan, 2015; Rodriguez et al., 2018), and thus, the high failure rate $(70 \%-80 \%)$ is at times experienced (Ahearne, Rapp, Mariadoss, \& Ganesan, 2012; Ghalenooie \& Sarvestani, 2016). This is primarily attributed to the lack of a suitable framework that guides CRM adoption (Laketa, Sanader, Laketa, \& Misic, 2015; P. Williams et al., 2017) as well as to the lack of awareness of the significant factors for CRM implementation such as security (Frygell, Hedman, \& Carlsson, 2017) and employee engagement (Zerbino, Aloini, Dulmin, \& Mininno, 2018). Additionally, the existing adoption theories fail to include environmental issues in the decision to adopt (Ngah, Zainuddin, \& Thurasamy, 2017). As such, the present study attempts to develop a comprehensive framework that enhances the level of CRM adoption rate among Palestinian SMEs. This would provide more indepth on how CRM can be adopted by SMEs in developing nations, particularly in Palestine.

\section{THEORETICAL BACKGROUND}

\section{Diffusion of innovation}

Rogers (2003) developed the Diffusion of Innovation Theory (DOI) in the middle of the 20th century. This theory defines innovation as ideas, customs, or objects perceived by individuals or adopting units as something new. It was contended that several innovative products' characteristics affect their adoption. These characteristics include their relative advantage, compatibility, complexity, divisibility, and observability.

Despite the extensive use of Rogers' (2003) model to shed light on innovation adoption, there were some criticisms leveled at the model. For instance, Azadegan and Teich (2010) pointed out that Rogers' theory neglected the importance of the nature of the different industries to deal with organizational and environmental factors. This leads to the examination of another relevant model, namely the TOE framework developed by Tornatzky and Fleischer (1990).

\section{Technology, organization and environment framework}

Tornatzky and Fleischer (1990) proposed an analytical method known as the TOE framework that has since become the most widely accepted technology theory. It underpins IS studies and end-user adoption at the level of organizations (Awa et al., 2016). TOE addresses different contexts: technological, organizational, and environmental (Tornatzky \& Fleischer, 1990). According to Piaralal, Nair, Yahya, and Karim (2015), the combination of the DOI theory and the TOE framework can provide a robust theoretical platform for SMEs to adopt green technology and examine innovative technology use through the consideration of the internal framework, integrated research, and external variables. 


\section{Resource-based view}

Resource-Based View (RBV) describes a firm's valuable and scarce resources and capabilities that can furnish it with a competitive advantage in the market (Al-Ansari, Pervan, \& Xu, 2013). Valuable resources and capabilities allow a firm to develop and implement strategies to bring about lower net costs and increase net revenues (Barney \& Arikan, 2001). Similarly, the contingency RBV of the firm posits that their consistency drives the productivity of the firm's resources and capabilities to the conditions within the environment (Liu \& Atuahene-Gima, 2018). Also, the resources of the firm are the basis of the RBV of a firm and are viewed as a firm's specific valuable assets (Keramati, Mehrabi, \& Mojir, 2010). As mentioned, a firm's resources can be its weaknesses or strengths, and they can be tangible or intangible (Carr \& Pearson, 1999).

Furthermore, the RBV theory Wernerfelt (1984) developed and proposed has been used extensively as an underlying theory for the examination of CRM dimensions-business performance relationship (Chao \& Chandra, 2012; Law, Fong, Chan, \& Fong, 2018). The RBV provides a framework for understanding how CRM provides economic value (Keramati et al., 2010). The RBV also enables researchers to shed light on the relationships among people, processes, and technologies and assisting in bringing about success through CRM systems (Chiles, 2015).

\section{Technology Acceptance Model (TAM)}

Davis (1989) develops the Technology Acceptance Model (TAM) for the prediction and determination of technology acceptance factors among users. According to Davis (1989), the TAM model contains two constructs, namely, perceived usefulness (PU) and perceived ease of use (PEOU). The perceived usefulness refers to the level to which an individual is convinced that a particular system use would contribute to enhancing his/her performance on the job, while the perceived ease of use refers to the level to which an individual is convinced that a particular system use would be effort-free.

\section{The Unified Theory of Acceptance and Use of Technology (UTAUT)}

The development of the Unified Theory of Acceptance and Use of Technology (UTAUT) was attributed to Venkatesh, Morris, Davis, and Davis (2003) , where the authors integrated eight dominant theories and models that have been extensive and successfully tested in prior studies dedicated to technology innovation adoption and diffusion in different fields (i.e., information systems, marketing, social psychology and management (M. D. Williams, Rana, \& Dwivedi, 2015). Moreover, evidence of the use of the theory in IS and the fields mentioned above is evident in the citations of the original work that proposed the theoretical evidence (Venkatesh, Thong, \& Xu, 2016).

UTAUT theory comprising of four major concepts, namely, performance expectancy (PE), effort expectancy (EE), social influence (SI), and facilitating conditions (FC). The major concepts are considered as independent variables that affect the dependent variables that take the form of behaviors and use. Furthermore, through the four major concepts, demographic characteristics of gender, age, experience, and system volunteers indirectly influence the independent variables. For instance, behavioral intention has been evidenced to predict the use of technology (Venkatesh et al., 2003).

Given the list of the theories above, only four theories of IT innovation adoption theories are related to the organizational level, namely TOE, DOI, and RBV. The remaining two theories are explaining adoption at an individual level, namely UTAUT and TAM (Oliveira \& Martins, 2011).

\section{FACTORS INFLUENCING CRM ADOPTION}

The literature review shows that fourteen factors influence the adoption of CRM in SMEs. Three factors were adapted from the DOI model. One factor was from the RBV model; another ten factors were extracted from the literature, and TOE was used for factor classification. Table 1 provides the definitions and sources of the factors. 
Table 1: Factors Influencing CRM Adoption

\begin{tabular}{|c|c|c|c|c|}
\hline No & Factor & Definition & Source(s) & Model/Theory \\
\hline 1 & $\begin{array}{l}\text { Compatibil- } \\
\text { ity }\end{array}$ & $\begin{array}{l}\text { The degree to which an in- } \\
\text { novation is perceived to be } \\
\text { consistent with existing val- } \\
\text { ues, past experiences, and } \\
\text { needs of potential adopters }\end{array}$ & Valmohammadi (2017) & DOI \\
\hline 2 & $\begin{array}{l}\text { Relative } \\
\text { Advantage }\end{array}$ & $\begin{array}{l}\text { The "degree to which an } \\
\text { innovation is perceived as } \\
\text { better than the idea it super- } \\
\text { sedes." }\end{array}$ & Vakola and Rezgui (2000) & DOI \\
\hline 3 & Complexity & $\begin{array}{l}\text { The level to which an inno- } \\
\text { vation is viewed to be diffi- } \\
\text { cult to understand and use }\end{array}$ & $\begin{array}{l}\text { Alhammadi, Stanier, and } \\
\text { Eardley (2015) }\end{array}$ & DOI \\
\hline 4 & $\begin{array}{l}\text { IT Infra- } \\
\text { structure }\end{array}$ & $\begin{array}{l}\text { IT assets (software, hard- } \\
\text { ware, and data), IT systems } \\
\text { and their components, net- } \\
\text { work, telecommunication } \\
\text { facilities, and applications }\end{array}$ & $\begin{array}{l}\text { Ghobakhloo, Tang, Sabouri, } \\
\text { and Zulkifli, (2012) }\end{array}$ & RBV \\
\hline 5 & Security & $\begin{array}{l}\text { The ability to protect con- } \\
\text { sumers' information and } \\
\text { transaction data to ensure } \\
\text { their privacy }\end{array}$ & $\begin{array}{l}\text { M. Mukred and Yusof } \\
(2017)\end{array}$ & $\begin{array}{l}\text { Literature re- } \\
\text { view }\end{array}$ \\
\hline 6 & $\begin{array}{l}\text { Top Man- } \\
\text { agement } \\
\text { Support }\end{array}$ & $\begin{array}{l}\text { The support provided by the } \\
\text { top executives of the organi- } \\
\text { zation that facilitates the } \\
\text { success of CRM implemen- } \\
\text { tation }\end{array}$ & $\begin{array}{l}\text { M. Mukred and Yusof } \\
(2017)\end{array}$ & $\begin{array}{l}\text { Literature re- } \\
\text { view }\end{array}$ \\
\hline 7 & $\begin{array}{l}\text { Financial } \\
\text { Support }\end{array}$ & $\begin{array}{l}\text { The financial resource that } \\
\text { covers all financial funds of } \\
\text { the organization }\end{array}$ & $\begin{array}{l}\text { M. Mukred, Yusof, Mokhtar, } \\
\text { and Fauzi (2018) }\end{array}$ & $\begin{array}{l}\text { Literature re- } \\
\text { view }\end{array}$ \\
\hline 8 & $\begin{array}{l}\text { Information } \\
\text { Policies }\end{array}$ & $\begin{array}{l}\text { A group of interconnected } \\
\text { laws, guidelines, principles, } \\
\text { regulations, rules, and pro- } \\
\text { cedures that guide the man- } \\
\text { agement and monitoring of } \\
\text { the information lifecycle }\end{array}$ & Nguyen and Waring (2013) & $\begin{array}{l}\text { Literature re- } \\
\text { view }\end{array}$ \\
\hline 9 & $\begin{array}{l}\text { Employee } \\
\text { Engage- } \\
\text { ment }\end{array}$ & $\begin{array}{l}\text { An employee who is aware } \\
\text { of the business context is } \\
\text { engaged and cooperate with } \\
\text { their peers to enhance com- } \\
\text { pany performance }\end{array}$ & Markos and Sandhya (2010) & $\begin{array}{l}\text { Literature re- } \\
\text { view }\end{array}$ \\
\hline 10 & $\begin{array}{l}\text { Customer } \\
\text { Pressure }\end{array}$ & $\begin{array}{l}\text { The demands and behaviors } \\
\text { of customers that make } \\
\text { companies adopt new tech- } \\
\text { nologies }\end{array}$ & Alhammadi et al. (2015) & $\begin{array}{l}\text { Literature re- } \\
\text { view }\end{array}$ \\
\hline 11 & $\begin{array}{l}\text { Competitive } \\
\text { Pressure }\end{array}$ & $\begin{array}{l}\text { The level of competitiveness } \\
\text { in the industry within which } \\
\text { the organization operates }\end{array}$ & $\begin{array}{l}\text { Salah, Yusof, \& Mohamed } \\
\text { (2018b); M. Mukred et al. } \\
\text { (2018) }\end{array}$ & $\begin{array}{l}\text { Literature re- } \\
\text { view }\end{array}$ \\
\hline
\end{tabular}




\begin{tabular}{|l|l|l|l|l|}
\hline No & \multicolumn{1}{|c|}{ Factor } & \multicolumn{1}{c|}{ Definition } & Source(s) & Model/Theory \\
\hline 12 & $\begin{array}{l}\text { Information } \\
\text { Integrity }\end{array}$ & $\begin{array}{l}\text { The information used in } \\
\text { such a manner that is trust- } \\
\text { ful and principled at the lev- } \\
\text { els of the individual and the } \\
\text { organization }\end{array}$ & Choo (2013) & $\begin{array}{l}\text { Literature re- } \\
\text { view }\end{array}$ \\
\hline 13 & $\begin{array}{l}\text { Information } \\
\text { Sharing }\end{array}$ & $\begin{array}{l}\text { The willingness to provide } \\
\text { information to others suita- } \\
\text { bly and collaboratively. This } \\
\text { behavior is well recognized } \\
\text { by top management, mainly } \\
\text { when it concerns internal } \\
\text { information sharing. }\end{array}$ & $\begin{array}{l}\text { Choo, Bergeron, Detlor, } \\
\text { and Heaton (2008) }\end{array}$ & $\begin{array}{l}\text { Literature re- } \\
\text { view }\end{array}$ \\
\hline 14 & $\begin{array}{l}\text { Attitude } \\
\text { toward } \\
\text { Adopting } \\
\text { Technology }\end{array}$ & $\begin{array}{l}\text { The overall effective re- } \\
\text { sponse of the individual to- } \\
\text { wards system adoption and } \\
\text { use }\end{array}$ & Venkatesh et al. (2003) & $\begin{array}{l}\text { Literature re- } \\
\text { view }\end{array}$ \\
\hline
\end{tabular}

These factors were drawn from an extensive range of frameworks in the literature. CRM practitioners then evaluate these factors in SMEs for verification and recommendation of new factors. These factors are expected to maximize the rate of CRM adoption among SMEs in developing countries, particularly Palestine.

\section{THEORETICAL FRAMEWORK AND RESEARCH HYPOTHESES}

There are various information system (IS) theories/models developed to study the acceptance of new technology. This study uses DOI, TOE, and RBV theories, which comprise of Technological context, Organizational context, Environmental context, and Information Culture context. The proposed framework is depicted in Figure 1. 


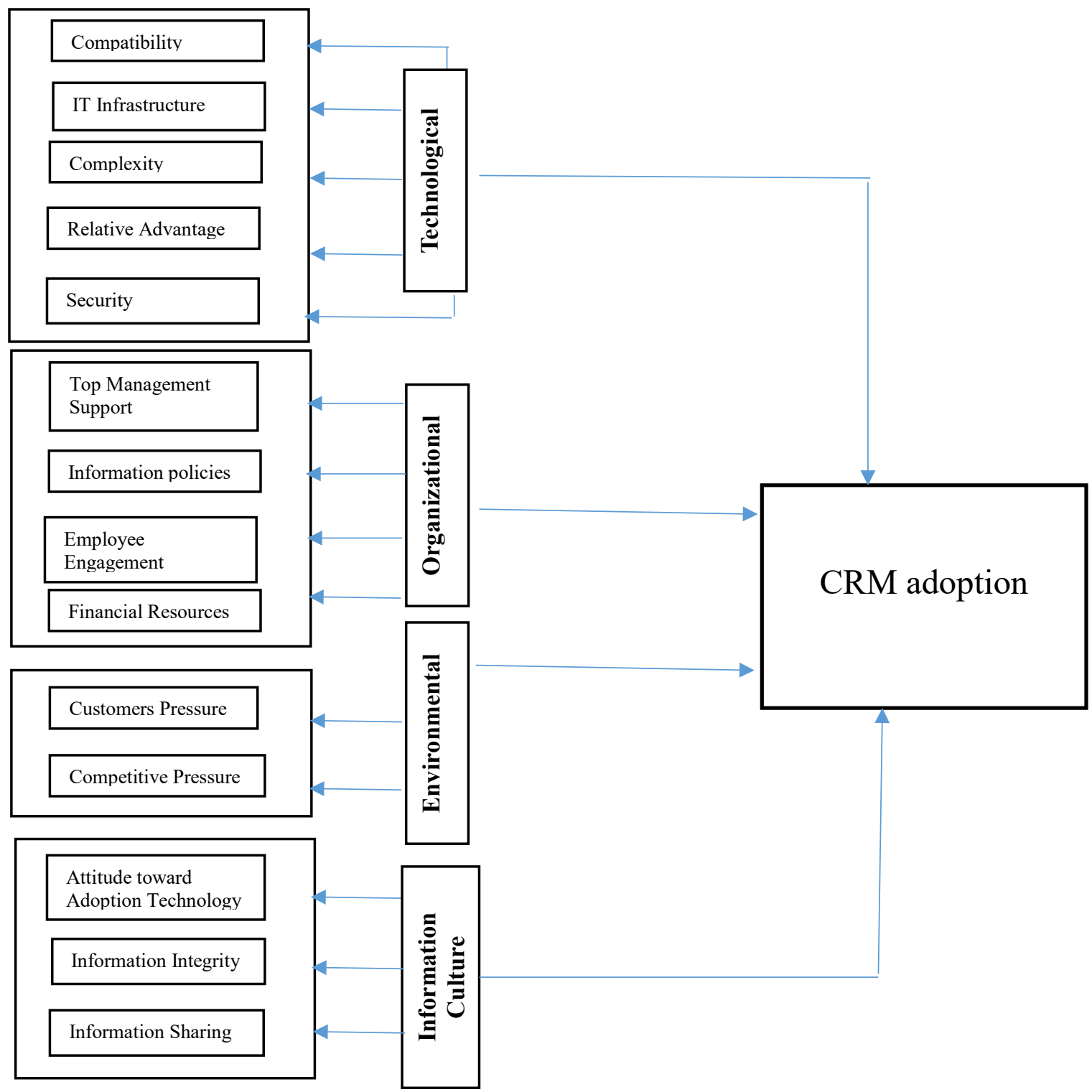

Figure 1: Proposed Conceptual framework for CRM Adoption

\section{TECHNOLOGICAL CONTEXT}

In the technological context, internal and external technologies are essential to enhance the productivity of the organization (Hoti, 2015). Small and medium-sized enterprises (SMEs) engaged in technology to boost their efficacy and efficiency productivity. The literature reveals that perceived usefulness, relative advantage, cost, security, compatibility, complexity, and observability (Ramayah, Ling, Taghizadeh, \& Rahman, 2016) are among the technical characteristic that should be taken into consideration. Several studies emphasized that IT infrastructure has increasingly become the core of business operations, such as CRM (Alshamaila, Papagiannidis, \& Li, 2013). However, previous studies indicate the three most essential characteristics of technology and innovation are relative advantage, compatibility, and complexity. On the other hand, security is a factor hindering the adoption of ecommerce (Ramayah et al., 2016). In light of this, this study considers compatibility, IT infrastructure, complexity, relative advantage, and security are the main determinants in the technological context. 


\section{Compatibility}

Several studies revealed that compatibility has a positive relationship with CRM adoption (Ahani, Rahim, \& Nilashi, 2017; Šebjan, Bobek, \& Tominc, 2014). Compatibility refers to the extent to which CRM is aligned with an organization's current experience and requirements. Compatibility is also considered to be a barrier when the SMEs are not ready technologically (Abou-Shouk, Lim, \& Megicks, 2016). Thus, in this study, the following hypothesis is proposed:

\section{H1: Compatibility has a positive effect on CRM adoption by Palestinian SMEs.}

\section{IT infrastructure}

Researchers have proposed various definitions of IT infrastructure over the years. For example, infrastructure in IT is the collection of hardware, software, networks, data centers, facilities, and associated equipment used for the development, testing, monitoring, management, and support of IS in an enterprise (Laan, 2013). New software system adoption may call for the enhancement or the addition of IT infrastructure to install new CRM software (Lee, Tang, \& Sugumaran, 2014). CRM failures could be avoided if CRM strategies are linked with IT infrastructure and the firm's stakeholders (employees, customers, channels) and infrastructure (Sen \& Sinha, 2011). Thus, the following hypothesis is proposed:

\section{H2: IT infrastructure has a positive effect on CRM adoption by Palestinian SMEs.}

\section{Complexity}

Most related studies reveal a significant relationship between complexity and the adoption of various technologies such as e-commerce adoption (Ahmad, Abu, Faziharudean, \& Mohamad, 2015), electronic records management (M. Mukred et al., 2018), cloud computing (Alshamaila et al., 2013), halal transportation services (Ngah, Zainuddin, \& Thurasamy, 2014), and CRM adoption (Steel, Dubelaar, \& Ewing, 2013). In contrast to other characteristics of innovation, complexity is negatively related to adoption probability (Vasseur \& Kemp, 2015). Although complexity may not be significant as relative advantage, it has been shown to prevent the adoption of technology (Rogers 2003). As such, the study proposes to test the undermentioned:

\section{H3: Complexity has a negative effect on CRM adoption by Palestinian SMEs.}

\section{Relative advantage}

Chavoshi, Sim, and Hee (2015) define relative advantage as the extent to which a CRM develops customer information that could enable a company to provide excellent customer service compared to traditional methods of meeting customer needs. Ahani et al. (2017) and Raut, Gardas, Jha, and Priyadarshinee (2017) consider a relative advantage, complexity, and compatibility as the most significant technological factors in examining the adoption of CRM. Therefore, the study proposes the following hypothesis for testing:

\section{H4: Relative Advantage has a positive effect on CRM adoption by Palestinian SMEs.}

\section{Security}

Security refers to the ability to protect customer information concerning their transaction details during transmission (Awa et al., 2016). Many studies have also identified security as a significant factor that influences the adoption of ICT (Awa et al., 2016). T. K. Sin, Choy, Lin, and Cyril (2009) revealed the security threat to be the most critical adoption barrier in various fields such as health information systems (A. Mukred, Singh, \& Safie, 2013) and electronic commerce (Ramayah et al., 2016). Therefore, the following hypothesis is proposed: 


\section{H5: Security has a positive effect on CRM adoption by Palestinian SMEs.}

\section{ORGANIZATIONAL CONTEXT}

The organizational context describes the organizational characteristics that are capable of facilitating or hindering the adoption of CRM systems. These characteristics include structures, resources, and processes (Ngah, Zainuddin, \& Thurasamy, 2017). According to Chavoshi et al., (2015), organizational characteristics refer to parameters influencing the adoption decision of the innovation and have the most significant impact on the adoption of CRM.

In a related study, successful innovation implementation was found to be significantly associated with the organization and environmental contexts (Wu \& Wu, 2005). Meanwhile, Garrido-Moreno and Padilla-Meléndez ( 2011) argue that the main reason for the failure of CRM projects is due to considering CRM as a technological tool and not addressing the various organizational and cultural changes involved. In this study, the organizational context represents top management support, information policies, social influence, and financial resources.

\section{Top management support}

Top management support is described as the level of support and understanding of top management concerning the functioning of IS and its contribution to its activities (Ragu-Nathan, Apigian, RaguNathan, \& Tu, 2004). In a related study on Social Customer Relationship Management, Ahani et al. (2017) revealed that top management support is a significant driver for CRM adoption. Frygell et al. (2017) indicate that top management support is the top critical factor required for CRM systems. Some other studies in the literature (M. Mukred et al., 2018) revealed that top management support has a significant influence on the adoption of technology. Hence, the following hypothesis is suggested:

\section{H6: Top management support has a positive effect on CRM adoption by Palestinian SMEs.}

\section{Information policies}

The policy is founded on the overall objectives and priorities of the organization. These organizational objectives inform the objectives of the information used in the organization. As a result, information refers to the context of whatever information is used in business and the principles the company will use to manage information, human resources employment, and technology use (Orna, 2008).

Few studies examined the relationship between organizational policies/processes and their influence on CRM performance (Peltier, Zahay, \& Lehmann, 2013). In order to successfully implement CRM, organizations have to demonstrate commitment and resource allocation and investment in culture, structure, and policies of the organization (Mohammed, Rashid, \& Tahir, 2017). Thus, this study proposes the following hypothesis for testing:

\section{H7: Information policies have a positive effect on CRM adoption by Palestinian SMEs.}

\section{Financial resources}

The adoption of new technology requires financial investment as technology needs to be installed, enhanced, and customized (C. Kim, Lee, Wang, \& Mirusmonov, 2015). Limited financial resources force owners/managers to be careful when investing appropriating capital on the technology, and, as such, small businesses are the only firms that have sufficient funds for IS adoption (Ghobakhloo \& Tang, 2013). This is because SMEs are generally characterized as having limited access to financial resources when compared to major firms (Ghobakhloo, Sabouri, Tang, \& Zulkifli, 2011), and such 
limited resources are common among small companies. This is a barrier to adopt new technologies (Hasani, Bojei, \& Dehghantanha, 2017).

Furthermore, Nguyen and Waring (2013) described CRM as being a sophisticated concept that requires vast financial resources to implement, along with a high level of company commitment. In this regard, the financial cost has a significant effect on the employees' intention to use CRM solutions (Šebjan et al., 2014). Thus, the following hypothesis is suggested:

H8: Financial resources have a positive effect on CRM adoption by Palestinian SMEs.

\section{Employee engagement}

Employee engagement is described as the involvement and satisfaction of the employees as well as their enthusiasm towards their work achievements (Harter, Schmidt, \& Hayes, 2002). According to Ncube and Jerie (2012), employee engagement is the harnessing of organization members to their work roles and encouraging their involvement (physical and emotional) in their role performances.

It is essential for project managers to comprehend and determine CRM key success factors along with the related variables (e.g., employee engagement) (Izogo \& Ogba, 2015). Employee engagement plays a crucial role in CRM success (Sultan, Hamza, \& Altawalbeh, 2018; Zerbino et al., 2018). Thus, the following hypothesis is suggested:

\section{H9: Employee engagement has a positive effect on CRM adoption by Palestinian SMEs.}

\section{ENVIRONMENTAL CONTEXT}

The business environment is a significant force that can motivate or prevent the adoption of innovation among firms (Rogers, 2003). The environmental context is the area within which firms conduct their business, as well as its industry and government dealings (Y. H. Li, 2008). It involves the issues that could exist in business involving competitors and business partners (Chiu, Chen, \& Chen, 2017). In this study, the environmental context represents customer pressure and competitive pressure.

\section{Competitive pressure}

Raut et al. (2017), defined competitive pressure as the level of pressure that is placed on an organization from the sector rivals. It is the pressure from the competitors that drive cloud computing adoption, primarily when technology directly affects competition. It is a strategic requirement to adopt new technologies to compete in the market (Saedi \& Iahad, 2013). Competition in the marketplace has a direct impact on the adoption of CRM systems (Alshawi et al. 2011). Competitive pressure from other Social CRM adopters may urge start-up firms to adopt and use SCRM technologies (Hasani et al., 2017; Wagner \& Wagner, 2013). Therefore, this study proposes that the following hypothesis be tested.

\section{H10: Competitive Pressure has a positive effect on CRM adoption by Palestinian SMEs.}

\section{Customers pressure}

"The customer is always right," is a common cliché used as a marketing strategy to ensure that customer satisfaction is achieved with the services that the company provides (Ngah et al., 2017). Customer pressure (CP) is the end consumers' (primary stakeholder group) requests and requirements for the firm to enhance its environmental and social performance (Ueki, 2016). Customer pressure has been ranked in third place as a top variable when it comes to e-customer relationship management solutions adoption (Sophonthummapharn, 2009). Similarly, Ahani et al. (2017) showed customer pressure and competitive pressure to be top drivers of social CRM adoption. Hence, the next hypothesis is as follows:

H11: Customers pressure has a positive effect on CRM adoption by Palestinian SMEs. 


\section{INFORMATION CULTURE CONTEXT}

Information culture is a significant aspect of the adoption of innovation in every organization (Grassian, Mizrachi, Roy, \& Kos, 2015; Oliver, 2011). Garrido-Moreno \& Padilla-Meléndez (2011) asset that the primary root cause behind CRM project failures does not lie in the strategy of the firm. Perhaps, failure ensues if CRMs are treated exclusively as technological tools. It is an information culture that plays a major role in determining the success of futures of CRM initiatives. In this study, the information culture context represents information integrity, information sharing, and attitude towards the adoption of technology.

\section{Attitude towards adopting technology}

Attitude toward technology use refers to the overall effective response of individuals towards system use (Venkatesh et al., 2003). In IT adoption, attitude towards use is deemed to be one of the significant predictors of technology adoption and extension in organizations (Ramayah et al., 2016). Also, attitude towards using technology is a significant factor when it comes to IS adoption (A. Mukred et al., 2013).

Besides, having positive attitudes towards IT use directly impacts the adoption of digital and computerized innovations throughout the globe (Chuang, Nakatani, \& Zhou, 2009). Researchers showed that individuals and organizations that generally have an open attitude towards change are more creative. They are more inclined to take risks and adopt innovations. They are also more likely to adopt (CRM) technology (Chavoshi et al., 2015). Therefore, this study developed the following hypothesis for testing:

\section{H12: Attitude toward adopting technology has a positive effect on CRM adoption by Pales-} tinian SMEs.

\section{Information integrity}

Information integrity is defined as the information used in such a manner that is trustworthy and principled at the levels of the individual and the organization (Choo, 2013). It is represented as the extent to which individuals use the information for their benefit (exercise of power or influence) (Furness, 2010). It is among the information behaviors that are used to characterize the information culture of an organization (Choo et al., 2008). More importantly, information integrity is a necessity in information management programs that affect information control. They must have accurate and formal information concerning individual and organizational performance (Furness, 2010). Hence, the next hypothesis is:

\section{H13: Information integrity has a positive effect on CRM adoption by Palestinian SMEs.}

\section{Information sharing}

Information sharing reflects the willingness to provide information to others suitably and collaboratively. This behavior is well recognized by top management, mainly when it concerns internal information sharing (Choo et al., 2008). Researchers in MIS revealed a strong positive influence of information sharing on the adaption of IS development and performance of organizations' (Al-Duwailah \& Ali, 2013; Peltier et al., 2013).

Previous studies indicate that information sharing is the fundamental function of CRM (Chien, Ma, \& Hou, 2015; L. Li \& Mao, 2012). Meanwhile, Brockman, Park, and Morgan, (2017) explain that CRM suppliers play a crucial role in their purchasing firms' success with information sharing coupled and trust as both influence the interpretation of information and its access to the purchasing firm. Based on the above discussion, this study proposes the following hypothesis:

H14: Information sharing has a positive effect on CRM adoption by Palestinian SMEs. 


\section{METHOD}

\section{QUESTIONNAIRE DESIGN}

From the literature review and email interviews, an instrument was developed to examine the factors that impact CRM adoption among Palestinian SMEs. Data was collected using a structured questionnaire. The questionnaire was divided into two parts. The first part enquired about the demographics of the respondents (i.e., gender, education level, position, type of company, position, years of experience), and the second part examined the selected variables, namely, Technological, organizational, environmental, and information culture context, in which the items were measured by a five-point Likert scale with the following ratings: 1: strongly disagree, 2: disagree, 3: slightly agree, 4: agree, and 5: strongly agree.

Overall, the questionnaire comprised of 76 measurement questions, which were grouped by the conceptual framework constructs. The measurement questions were developed through an extensive literature review. Minor modifications were made on these items to fit the SMEs in Palestine. Table 2 lists the sources of the items that were adopted from the literature.

Table 2: Measurement items references

\begin{tabular}{|l|c|l|}
\hline \multicolumn{1}{|c|}{ Variable } & \multicolumn{1}{|c|}{$\begin{array}{c}\text { No. of ques- } \\
\text { tions }\end{array}$} & \multicolumn{1}{|c|}{ References } \\
\hline Compatibility & 5 & Alrousan and Jones (2016) \\
\hline IT Infrastructure & 5 & $\begin{array}{l}\text { Mishra, Anderson, Angst, and Agarwal } \\
\text { (2012) }\end{array}$ \\
\hline complexity & 5 & $\begin{array}{l}\text { Ching and Ellis (2004); Alrousan and } \\
\text { Jones (2016) }\end{array}$ \\
\hline Relative advantage & 5 & Son, Narasimhan, and Riggins (2005) \\
\hline Security & 6 & Shergill and Chen (2005) \\
\hline $\begin{array}{l}\text { Top Management } \\
\text { Support }\end{array}$ & 6 & $\begin{array}{l}\text { Grover and Goslar (1993); Eid and El- } \\
\text { Gohary (2014) }\end{array}$ \\
\hline $\begin{array}{l}\text { Information Policies } \\
\text { Financial Resources }\end{array}$ & 6 & $\begin{array}{l}\text { E. Y. Li and Shani (1991); Abrahamson } \\
\text { and Goodman-Delahunty (2013) }\end{array}$ \\
\hline $\begin{array}{l}\text { Employee Engage- } \\
\text { ment }\end{array}$ & 5 & $\begin{array}{l}\text { Tung, Chang, and Chou (2008); Lai, } \\
\text { Lin, and Tseng (2014) }\end{array}$ \\
\hline Customer Pressure & 3 & Custom Insight (2019) \\
\hline Competitive Pressure & 4 & Ngah et al.(2014) \\
\hline $\begin{array}{l}\text { Attitude Towards } \\
\text { Adoption Technology }\end{array}$ & 4 & Ramayah et al. (2016) \\
\hline Information Integrity & 5 & Teo et al., (2006) \\
\hline Information Sharing & 5 & Sinitsyna (2014) \\
\hline CRM Adoption & 5 & $\begin{array}{l}\text { Venkateshn and Bala (2008); Chen } \\
\text { (2012) }\end{array}$ \\
\hline
\end{tabular}

\section{Data collection procedure and sample data}

Data for this study was gathered from employees working in SMEs in Palestine. This includes general managers, heads of department, operational employees' technology who are involved in activities 
related to CRM technology, and the adoption decision. The e-version of the questionnaire was uploaded to the survey website, coupled with an introduction page that provided the definitions of CRM and SMEs. An invitation letter was then followed, and the survey link to the SME employees.

From a total of 420 respondents who received the link, 331 (79\%) filled and returned the survey. This response rate was achieved after countless efforts to encourage the participation of respondents in the study. According to Kangu (2017), a response rate of 50\% or more is sufficient and acceptable for analysis, $60 \%$ and over is good, and over $70 \%$ is excellent. Thus, the rate of response to this internet survey is acceptable in this study.

\section{Sample profile}

The demographic data collected include age, gender, educational level, job level, department, and organizational tenure. This is suggested even if the theoretical framework does not need the variables as the obtained data will shed insight into the sample characteristics in the report following data analysis (Sekaran, 2009). These demographic variables, along with their frequencies, percentages, and background information, are shown in Table 3.

Table 3: Summary of Descriptive Demographic Factors

\begin{tabular}{|l|l|l|l|}
\hline & \multicolumn{1}{|c|}{ Description } & Frequency & Percentage \\
\hline Gender & Male & 269 & 81.3 \\
& Female & 62 & 18.7 \\
\hline Level of education & Diploma & 30 & 9.1 \\
& Bachelor's Degree & 189 & 57.1 \\
& Master's Degree & 85 & 25.7 \\
& Doctorate Degree & 27 & 8.1 \\
\hline Type of company & Information and Communi- & 95 & 28.7 \\
& cations Technology (ICT) & 47 & 14.2 \\
& Product company & 92 & 27.8 \\
& Service company & 97 & 29.3 \\
& Sales company & & \\
\hline Position in organi- & General manager & 102 & 30.8 \\
zation & Head of the department & 155 & 46.8 \\
& Operational employees & 74 & 22.4 \\
\hline Number of em- & $5-19$ & 199 & 60.1 \\
ployees in an or- & $20-49$ & 132 & 39.9 \\
ganization & & & \\
\hline Years of experience & $<1$ year & 8 & 2.4 \\
& $1-5$ years & 72 & 21.8 \\
& $5-10$ years & 52 & 15.7 \\
& $>10$ years & 199 & 60.1 \\
\hline Age & $20-30$ years old & 64 & 19.3 \\
& 31-40 years old & 98 & 29.6 \\
& $41-50$ years old & 66 & 20 \\
& 51 and above & 31.1 \\
\hline
\end{tabular}

The demographic information reveals a few female respondents. This shows that there are more males work in SMEs in Palestine. This is related to the Palestinian culture where male-dominated the 
IT technology fields than the female. Such a scenario is also applicable to the other fields of works in Palestine (Alfoqahaa, 2018).

In this study, the researcher used the software packages SmartPLS 2.0. It provides results for several types of variables regardless of which metric, quasi-metric, ordinal, or categorical scales they use (Hair, Ringle, \& Sarstedt, 2013). For prediction and explanation, when the phenomenon under study is relatively new, or when the theoretical model is complex with a large number of variables and indicator variables, a PLS approach is often more suitable (Chin \& Newsted, 1999; Vinzi, Chin, Henseler, \& Wang, 2010). Yoo and Alavi (2001) and Urbach and Ahlemann (2010) that they chose PLS in preference to several other SEM tools, including EQS, AMOS, and LISREL, because, unlike other tools, PLS does not require a large sample size. Also, PLS is more suitable when the objective of the study is causal predictive testing, rather than the testing of an entire theory.

\section{Sampling Technique and Design}

The sampling technique can divide the population into two types: probability sampling and nonprobability sampling. Probability sampling is the type of sampling where the possibility of selecting each case from the population is equal for all cases, while non-probability sampling is where the chance of being selected is unknown and is not the same for each case. Probability sampling is mostly used in survey-based research strategies, where inferences need to make from the sample concerning the population to determine the answer to the research questions and to meet the research objectives (Saunders, Lewis, \& Thornhill 2009). In the probability sampling design, more commonly known as simple random sampling. Random sampling design is the most efficient as for the same sample subjects number; it provides accurate and detailed information (Sekaran, 2009), More importantly, probability sampling designs are adopted when the sample representativeness is of significance to generalization to the wider population. In this study, the probability random sampling method is adopted for collecting data.

\section{Analysis of Data AND Presenting Results}

The evaluation process in PLS-SEM consists of two main phases: (1) assessing the measurement model and (2) assessing the structural model (Soltani, Zareie, Milani, \& Navimipour, 2018). The combination of the structural model with the measurement model can lead to a complete structural equation model (Urbach \& Ahlemann, 2010). The examination of the measurement model was done in the first stage to identify the relationship between indicators and their items (Henseler, Ringle, \& Sinkovics, 2009). The structural model evaluation of hypothesis testing was done in the second stage.

\section{MEASUREMENT MODEL}

The present study is guided by the roadmap of PLS-SEM assessment from Hair, Sarstedt, Hopkins, and Kuppelwieser (2014). Since the study measures reflect the relationships of the constructs, it is crucial to apply the reliability and validity assessment methods, including: (i) indicator reliability (ii) internal consistency reliability (iii) convergent validity (iv) discriminant validity assessment.

\section{Indicator reliability}

Reliability refers to the assessment of response consistency, or, "the degree to which an instrument measures, in the same way, each time under the same conditions" (Kangu, 2017). The outer loading is one of the assessment methods used to confirm indicator reliability. The assessment of the outer loading is carried out for each variable to guarantee that each item measuring the variable adequately loads on it with 0.70 or more (Hair, Sarstedt, et al., 2014).

Based on the results presented in Table 4, nine indicators were deleted since their outer loading values were under the acceptable level of 0.7 suggested by, leaving 72 out of 81 indicators are retained after the data process. 


\section{Internal consistency reliability}

For internal consistency reliability, two assessment methods were used. These are Cronbach's alpha and composite reliability. For the confirmation of the consistency of the items measuring the same construct, it is vital for the composite reliability to be 0.7 or over (Hair, Sarstedt, et al., 2014). Both tests ensure the items internal consistency in the same variable, which indicates that the construct items are grouped with sufficient consistency, i.e., over $0 . * 7$. (See Table 4)

\section{Convergent validity}

In the convergent validity test, the level to which the two measures of a single concept are correlated is measured. An alternative measure of a concept may be identified, and they can be correlated with the summated scale (Hair, Black, Babin, \& Anderson, 2014). There are three ways in which the relative convergent validity among item measures can be estimated: factor loadings (outer loading), construct reliability which has been explained earlier, and average variance extracted (Hair, Black, et al., 2014). Average Variance Extracted (AVE). AVE value is obtained through the mean-variance extracted for the items loading on a construct and is a summarized version of the convergence indicator. An AVE value of 0.5 or over indicates adequate convergence (Hair, Black, et al., 2014). Table 4 shows the AVE for all the constructs ranged between 0.651 and 0.73 , which means that convergent validity was confirmed for all the variables, and no construct had to remove.

Table 4: Factor Loading

\begin{tabular}{|c|c|c|c|c|c|c|}
\hline Factor & Item & $\begin{array}{c}\text { Outer } \\
\text { Loading } \\
\text { (Before) }\end{array}$ & $\begin{array}{c}\text { Outer } \\
\text { Loading } \\
\text { (After) }\end{array}$ & $\begin{array}{l}\text { Composite } \\
\text { Reliability }\end{array}$ & $\begin{array}{c}\text { Cronbach's } \\
\text { Alpha }\end{array}$ & AVE \\
\hline \multirow{5}{*}{$\begin{array}{l}\text { Compatibility } \\
\text { (CMP) }\end{array}$} & CMP1 & 0.624 & & \multirow{5}{*}{0.913} & \multirow{5}{*}{0.873} & \multirow{5}{*}{0.725} \\
\hline & CMP2 & 0.838 & 0.852 & & & \\
\hline & CMP3 & 0.774 & 0.797 & & & \\
\hline & CMP4 & 0.910 & 0.926 & & & \\
\hline & CMP5 & 0.819 & 0.825 & & & \\
\hline \multirow{5}{*}{$\begin{array}{l}\text { IT Infrastruc- } \\
\text { ture (ITI) }\end{array}$} & ITI1 & 0.825 & 0.831 & \multirow{5}{*}{0.898} & \multirow[t]{5}{*}{0.848} & \multirow{5}{*}{0.689} \\
\hline & ITI2 & 0.894 & 0.910 & & & \\
\hline & ITI3 & 0.843 & 0.859 & & & \\
\hline & ITI4 & 0.703 & 0.708 & & & \\
\hline & ITI5 & 0.334 & & & & \\
\hline \multirow{5}{*}{$\begin{array}{l}\text { Complexity } \\
(\mathrm{CMX})\end{array}$} & CMX1 & 0.858 & 0.858 & \multirow{5}{*}{0.930} & \multirow{5}{*}{0.905} & \multirow{5}{*}{0.726} \\
\hline & CMX2 & 0.897 & 0.897 & & & \\
\hline & CMX3 & 0.809 & 0.808 & & & \\
\hline & CMX4 & 0.866 & 0.867 & & & \\
\hline & CMX5 & 0.826 & 0.826 & & & \\
\hline \multirow{5}{*}{$\begin{array}{l}\text { Relative ad- } \\
\text { vantage } \\
\text { (RLA) }\end{array}$} & RLA1 & 0.808 & 0.823 & \multirow{5}{*}{0.885} & \multirow{5}{*}{0.822} & \multirow{5}{*}{0.652} \\
\hline & RLA2 & 0.851 & 0.849 & & & \\
\hline & RLA3 & 0.752 & 0.778 & & & \\
\hline & RLA4 & 0.754 & 0.776 & & & \\
\hline & RLA5 & 0.458 & & & & \\
\hline
\end{tabular}




\begin{tabular}{|c|c|c|c|c|c|c|}
\hline Factor & Item & $\begin{array}{c}\text { Outer } \\
\text { Loading } \\
\text { (Before) }\end{array}$ & $\begin{array}{c}\text { Outer } \\
\text { Loading } \\
\text { (After) }\end{array}$ & $\begin{array}{l}\text { Composite } \\
\text { Reliability }\end{array}$ & $\begin{array}{c}\text { Cronbach's } \\
\text { Alpha }\end{array}$ & AVE \\
\hline \multirow{6}{*}{$\begin{array}{l}\text { Security } \\
\text { (SEC) }\end{array}$} & SEC1 & 0.805 & 0.811 & \multirow{5}{*}{0.908} & \multirow{5}{*}{0.874} & \multirow{5}{*}{0.664} \\
\hline & SEC2 & 0.772 & 0.769 & & & \\
\hline & SEC3 & 0.458 & & & & \\
\hline & SEC4 & 0.898 & 0.904 & & & \\
\hline & SEC5 & 0.806 & 0.817 & & & \\
\hline & SEC6 & 0.768 & 0.765 & \multirow{5}{*}{0.940} & \multirow{5}{*}{0.923} & \multirow{5}{*}{0.723} \\
\hline \multirow{6}{*}{$\begin{array}{l}\text { Top man- } \\
\text { agement } \\
\text { support } \\
\text { (TMS) }\end{array}$} & TMS1 & 0.796 & 0.796 & & & \\
\hline & TMS2 & 0.846 & 0.845 & & & \\
\hline & TMS3 & 0.857 & 0.857 & & & \\
\hline & TMS4 & 0.849 & 0.849 & & & \\
\hline & TMS5 & 0.850 & 0.850 & & & \\
\hline & TMS6 & 0.796 & 0.901 & & & \\
\hline \multirow{6}{*}{$\begin{array}{l}\text { Employee } \\
\text { Engagement } \\
(\mathrm{EEN})\end{array}$} & EEN1 & 0.794 & 0.796 & \multirow{6}{*}{0.902} & \multirow{6}{*}{0.870} & \multirow{6}{*}{0.605} \\
\hline & EEN2 & 0.745 & 0.745 & & & \\
\hline & EEN3 & 0.752 & 0.751 & & & \\
\hline & EEN4 & 0.810 & 0.810 & & & \\
\hline & EEN5 & 0.787 & 0.786 & & & \\
\hline & EEN6 & 0.779 & 0.778 & & & \\
\hline \multirow{7}{*}{$\begin{array}{l}\text { Information } \\
\text { policies } \\
\text { (INP) }\end{array}$} & INP1 & 0.729 & 0.707 & \multirow{7}{*}{0.900} & \multirow{7}{*}{0.866} & \multirow{7}{*}{0.601} \\
\hline & INP2 & 0.757 & 0.739 & & & \\
\hline & INP3 & 0.622 & & & & \\
\hline & INP4 & 0.755 & 0.774 & & & \\
\hline & INP5 & 0.704 & 0.725 & & & \\
\hline & INP6 & 0.850 & 0.889 & & & \\
\hline & INP7 & 0.781 & 0.803 & & & \\
\hline \multirow{5}{*}{$\begin{array}{l}\text { Financial } \\
\text { resource (FR) }\end{array}$} & FR1 & 0.856 & 0.855 & \multirow{5}{*}{0.915} & \multirow{5}{*}{0.884} & \multirow{5}{*}{0.685} \\
\hline & FR2 & 0.816 & 0.813 & & & \\
\hline & FR3 & 0.880 & 0.880 & & & \\
\hline & FR4 & 0.816 & 0.818 & & & \\
\hline & FR5 & 0.765 & 0.767 & & & \\
\hline \multirow{3}{*}{$\begin{array}{l}\text { Customers } \\
\text { Pressure } \\
(\mathrm{CUP})\end{array}$} & CUP1 & 0.901 & 0.902 & \multirow{3}{*}{0.893} & \multirow[b]{3}{*}{0.819} & \multirow{3}{*}{0.738} \\
\hline & CUP2 & 0.909 & 0.909 & & & \\
\hline & CUP3 & 0.759 & 0.757 & & & \\
\hline \multirow{4}{*}{$\begin{array}{l}\text { Competitive } \\
\text { pressure } \\
\text { (COP) }\end{array}$} & COP1 & 0.865 & 0.868 & \multirow{4}{*}{0.908} & \multirow{4}{*}{0.865} & \\
\hline & COP2 & 0.834 & 0.832 & & & \\
\hline & COP3 & 0.822 & 0.821 & & & \\
\hline & COP4 & 0.849 & 0.850 & & & 0.711 \\
\hline
\end{tabular}




\begin{tabular}{|c|c|c|c|c|c|c|}
\hline Factor & Item & $\begin{array}{c}\text { Outer } \\
\text { Loading } \\
\text { (Before) }\end{array}$ & $\begin{array}{c}\text { Outer } \\
\text { Loading } \\
\text { (After) }\end{array}$ & $\begin{array}{l}\text { Composite } \\
\text { Reliability }\end{array}$ & $\begin{array}{c}\text { Cronbach's } \\
\text { Alpha }\end{array}$ & AVE \\
\hline \multirow{4}{*}{$\begin{array}{l}\text { Attitude to- } \\
\text { ward adop- } \\
\text { tion technol- } \\
\text { ogy (ATA) }\end{array}$} & ATA1 & 0.864 & 0.893 & \multirow{4}{*}{0.869} & \multirow{4}{*}{0.783} & \multirow{4}{*}{0.689} \\
\hline & ATA2 & 0.847 & 0.835 & & & \\
\hline & ATA3 & 0.754 & 0.758 & & & \\
\hline & ATA4 & 0.634 & & & & \\
\hline \multirow{5}{*}{$\begin{array}{l}\text { Information } \\
\text { sharing (INS) }\end{array}$} & INS1 & 0.824 & 0.849 & \multirow{5}{*}{0.902} & \multirow{5}{*}{0.855} & \multirow{5}{*}{0.697} \\
\hline & INS2 & 0.891 & 0.903 & & & \\
\hline & INS3 & 0.45601 & & & & \\
\hline & INS4 & 0.776 & 0.768 & & & \\
\hline & INS5 & 0.795 & 0.812 & & & \\
\hline \multirow{5}{*}{$\begin{array}{l}\text { Information } \\
\text { integrity } \\
\text { (INI) }\end{array}$} & INI1 & 0.843 & 0.855 & \multirow{5}{*}{0.915} & \multirow{5}{*}{0.879} & \multirow{5}{*}{0.729} \\
\hline & INI2 & 0.897 & 0.905 & & & \\
\hline & INI3 & 0.841 & 0.843 & & & \\
\hline & INI4 & 0.571 & & & & \\
\hline & INI5 & 0.808 & 0.810 & & & \\
\hline \multirow{5}{*}{$\begin{array}{l}\text { CRM Adop- } \\
\text { tion (CAD) }\end{array}$} & CAD1 & 0.844 & 0.860 & \multirow{5}{*}{0.911} & \multirow{5}{*}{0.869} & \multirow{5}{*}{0.719} \\
\hline & CAD2 & 0.882 & 0.879 & & & \\
\hline & CAD3 & 0.835 & 0.850 & & & \\
\hline & CAD4 & 0.773 & 0.800 & & & \\
\hline & CAD5 & 0.638 & & & & \\
\hline
\end{tabular}

\section{Discriminant validity}

This type of validity tests whether different items not associated with measuring the variable are measuring some other variable. The test is also known as Fornell and Larcker criterion, and the technique calls for the construction of a matrix of latent variables correlating with the entire diagonal values replaced by the square root of the variable's AVE values (Fornell \& Larcker, 1981; Hair et al., 2013). Based on the rule of thumb, the diagonal cell value has to be higher compared to the values in the whole column and row. Table 5 shows the Fornell and Larcker criterion matrix for the sixteen research variables. The results show that the values in the diagonal cell are always higher than their associated row and column values.

\section{ASSESSMENT OF STRUCTURE MODEL}

The structural model contains one or more dependency relationships that relate the model's constructs to each other. This study employed the bootstrapping method with 5000 re-samples to conduct an estimation of the statistical significance of the hypothesized model (Hair, Hult, Ringle, Sarstedt, \& Thiele, 2017). In addition to providing a description of the significance of the relationships, Hair, Black, et al. (2014) explained that researchers have to present the coefficient of determination (R2), predictive relevance (Q2), and effect size (F2) with path significance to shed light on the variance of the endogenous variable. In this regard, Table 6 shows the assessments in structural model analysis and the value of the threshold limit that used in this study.

For CRM adoption, the endogenous latent construct, R2 value, was found to be 0.813 , with Q2 value of 0.545 . The values indicate the strong predictive power of the exogenous (independent) constructs, with a large proportion of CRM adoption predictive relevance, as shown in Figure 2. 
Table 5: Discriminant Validity

\begin{tabular}{|c|c|c|c|c|c|c|c|c|c|c|c|c|c|c|}
\hline 昜 & 留 & 瞕 & 임 & 搨 & & 要 & Tx & 囷 & ఏ્త & ○ิ & $\frac{8}{8}$ & 8 & 点 & \\
\hline 它: & 응 & 通 & $\begin{array}{l}\text { 웅 } \\
\text { o } \\
\text { gi }\end{array}$ & 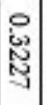 & 있 & ?. & 是 & 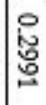 & $\begin{array}{l}\text { ㅇ } \\
\text { 总 } \\
\text { N }\end{array}$ & 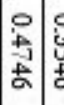 & \begin{tabular}{l|l}
0 \\
$\mathrm{c}$ \\
$\mathrm{u}$ \\
$\mathrm{a}$ \\
$\mathrm{a}$
\end{tabular} & 足 & : & 急 \\
\hline 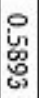 & $\begin{array}{l}\text { : } \\
\text { : }\end{array}$ & $\mid$ & $\begin{array}{l}\text { : } \\
\text { a } \\
\text { 心 }\end{array}$ & $\begin{array}{l}\text { 是 } \\
\text { 恖 }\end{array}$ & : & & 怘 & 总 & 只 & 惫 & $\begin{array}{ll}. \\
\\
\end{array}$ & $\begin{array}{l}0 \\
0 \\
0 \\
0\end{array}$ & & $\tilde{\beta}$ \\
\hline 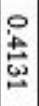 & $\begin{array}{l}\text { 号 } \\
\text { 总 } \\
\end{array}$ & 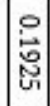 & $\begin{array}{l}\text { P } \\
\text { 走 } \\
\text { 去 }\end{array}$ & 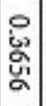 & $\begin{array}{l}0 \\
\mathbb{8} \\
\mathbb{8} \\
\end{array}$ & 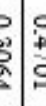 & 姃 & 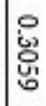 & 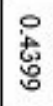 & 虽 & 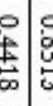 & | & & 目 \\
\hline 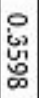 & 星 & 居 & 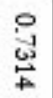 & 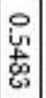 & $\begin{array}{l}\text { : } \\
\text { : } \\
\text { : }\end{array}$ & 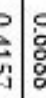 & 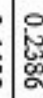 & $\begin{array}{l}\text { 옹 } \\
\text { 恶 }\end{array}$ & 总 & 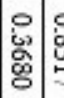 & 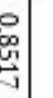 & & & 是 \\
\hline 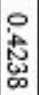 & 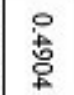 & : & 景 & $\begin{array}{l}\text { 灾 } \\
\text { ڤ్ }\end{array}$ & 总 & 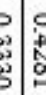 & : & 递 & 兽 & $\mid$\begin{tabular}{|}
0 \\
o \\
音 \\
|
\end{tabular} & & & & ᄋ్త \\
\hline 点 & $\underset{:}{\stackrel{i}{\Xi}}$ & \begin{tabular}{l} 
오․ \\
\multirow{2}{*}{}
\end{tabular} & 옹 & 잉 & 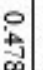 & 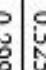 & : & 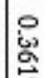 & 总 & & & & & $\mathcal{G}$ \\
\hline$\sqrt{3}$ & & & & & & 10 & & 6 & & & & & & \\
\hline $\begin{array}{l}\circ \\
\vdots \\
\vdots\end{array}$ & $\stackrel{8}{\stackrel{8}{G}}$ & 谂 & $\begin{array}{l}\text { 영 } \\
\text { 。 }\end{array}$ & 怘 & : & 8 & & 恿 & & & & & & 团 \\
\hline & & & & 0 & ol & & & & & & & & & \\
\hline $\begin{array}{l}\text { 怘 } \\
\text { 心. } \\
\text { : }\end{array}$ & ${ }^{\circ} 0$ & 号 & $\begin{array}{l}0 \\
\stackrel{0}{0} \\
\mathbf{g}\end{array}$ & 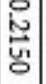 & 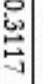 & 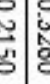 & 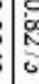 & & & & & & & 团 \\
\hline 足 & $\begin{array}{l}\text { 足 } \\
\text { 点 }\end{array}$ & 잉 & $\begin{array}{l}\text { 엉 } \\
\text { 怘 } \\
\text { 品 }\end{array}$ & $\begin{array}{l}\text { : } \\
\text { 心. } \\
\text { }\end{array}$ & : & $\begin{array}{ll}0 \\
S_{3}\end{array}$ & & & & & & & & 冢 \\
\hline & & 0 & & 01 & ol & 0 & & & & & & & & \\
\hline 芯 & 胥 & $\begin{array}{l}5 \\
0 \\
0\end{array}$ & t & 产 & 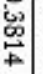 & , & & & & & & & & 辛 \\
\hline 8 & : & 이 & 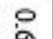 & 잉 & 잉 & & & & & & & & & \\
\hline $\begin{array}{l}\text { 总 } \\
\ddagger\end{array}$ & 点 & ఏ & 心 & 8 & 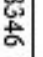 & & & & & & & & & G \\
\hline 8 & 옹 & & ㅇ & 잉 & & & & & & & & & & \\
\hline 帠 & gั & 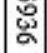 & 㟢 & 巳 & & & & & & & & & & 日 \\
\hline 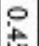 & i & 이 & : & & & & & & & & & & & 0 \\
\hline un & 完 & |ूog & 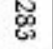 & & & & & & & & & & & 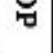 \\
\hline 8 & $\stackrel{i}{N}$ & & & & & & & & & & & & & 窝 \\
\hline & 昆 & - & & & & & & & & & & & & \\
\hline \pm & : & & & & & & & & & & & & & 6 \\
\hline & 点 & & & & & & & & & & & & & \\
\hline & & & & & & & & & & & & & & 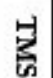 \\
\hline
\end{tabular}


Table 6: Structural model assessment

\begin{tabular}{|l|l|}
\hline $\begin{array}{l}\text { Structural Model } \\
\text { Assessment }\end{array}$ & \multicolumn{1}{|c|}{ Threshold Limit } \\
\hline $\begin{array}{l}\text { Coefficient of the } \\
\text { determinant (R2) }\end{array}$ & $\begin{array}{l}\text { R2 value around 0.75 is strong, around (0.5-.75) is } \\
\text { moderate, around }(0.2-0.5) \text { is weak }\end{array}$ \\
\hline $\begin{array}{l}\text { Predictive Relevance } \\
(\mathrm{Q} 2)\end{array}$ & $\begin{array}{l}\text { Q2 value around 0.35 is large, around }(0.15-0.35), \text { is } \\
\text { medium, around }(0.02-0.15), \text { is small }\end{array}$ \\
\hline Effect size (F2) & $\begin{array}{l}\text { F2 value around 0.35 is large, around 0.15 is medi- } \\
\text { um, around 0.02 and below is small }\end{array}$ \\
\hline path coefficients $(\beta)$ & $\begin{array}{l}\text { Accept if t-value }>1.65 \text { and p-value }<0.05, \text { reject if } \\
\text { t- value }<1.65 \text { and } p \text {-value }>0.05\end{array}$ \\
\hline
\end{tabular}

Source: Hair et al. (2014 b)

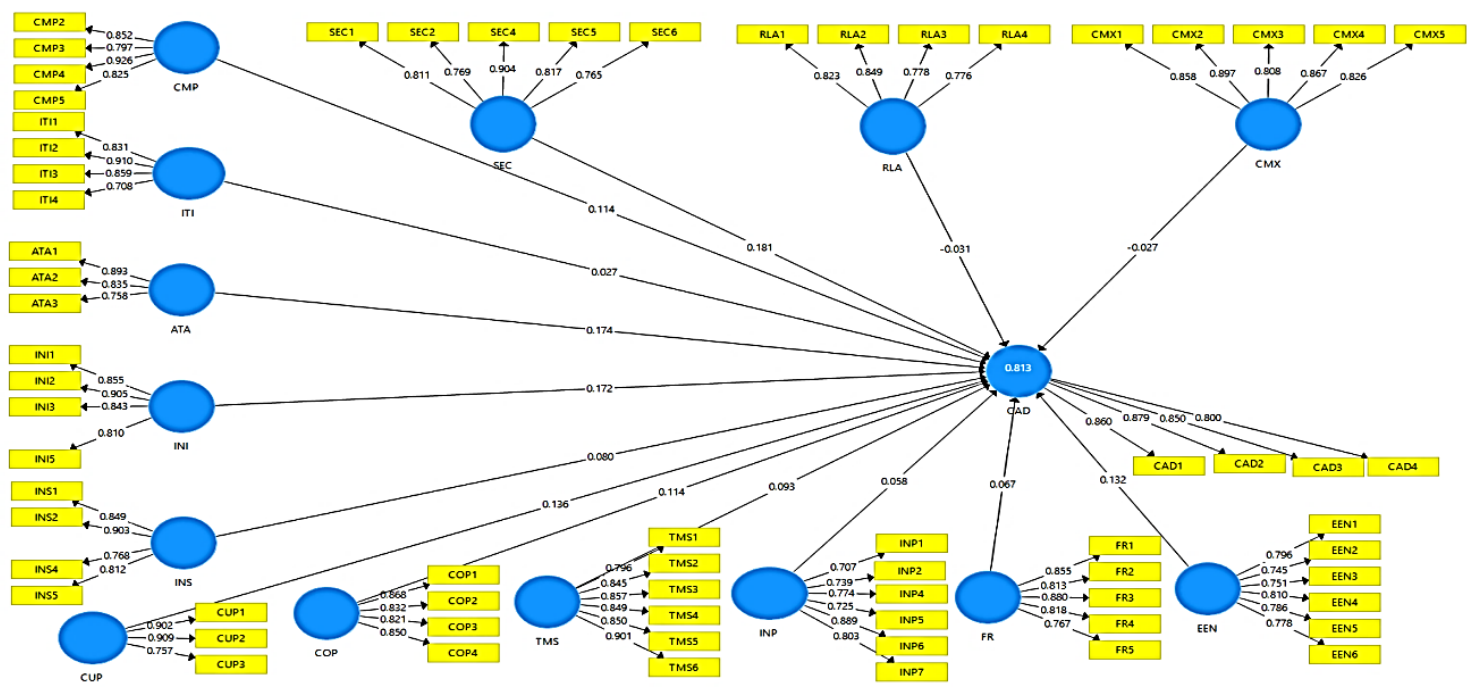

Figure 2: Structural model for testing the direct effects of the variables

In particular, Effect size (F2) represents the relative effect of a particular exogenous latent variable on the endogenous latent variable through a change in $\mathrm{R} 2$. F2 value is obtained by calculating the increased R2 of the latent variable towards the connected path, relative to the proportion of unexpected variance of the latent variable (Hair, Hult, Ringle, Sarstedt, 2016). Table 7 shows that all the effect size was found to be within the recommended values.

Table 7: Effect Size

\begin{tabular}{|l|l|l|l|l|l|c|c|c|c|c|c|c|c|}
\hline ATA & CMP & CMX & COP & CUP & EEN & FR & INI & INP & INS & ITI & RLA & SEC & TMS \\
\hline 0.090 & 0.02 & 0.002 & 0.041 & 0.053 & 0.063 & 0.18 & 0.057 & 0.13 & 0.17 & 0.041 & 0.003 & 0.097 & 0.028 \\
\hline
\end{tabular}

Next, the significance of direct relationships is evaluated by applying 5,000 bootstrap subsamples and critical t-values greater than \pm 1.65 (one-tailed test). Findings of the analysis suggest that $11(\mathrm{H} 1, \mathrm{H} 2$, H4, H5, H6, H7, H8, H9, H10, H13, and H14) out of 14 hypotheses were supported and significant at $\mathrm{p} \mathbf{1} 0.05$, with the beta values of H3, H11, and H12 were not supported (see Table 8 for all results). 
Table 8: Hypothesized Direct Effects of the Variables

\begin{tabular}{|l|l|l|l|l|l|}
\hline Hypotheses & & $\begin{array}{c}\text { Path Coef- } \\
\text { ficient }\end{array}$ & t Statistics & p-Value & \\
\hline H1 & CMP $\rightarrow$ CAD & 0.114 & 3.146 & 0.001 & Supported \\
\hline H2 & ITI $\rightarrow$ CAD & 0.027 & 0.869 & 0.193 & Unsupported \\
\hline H3 & CMX $\rightarrow$ CAD & -0.027 & 0.732 & 0.232 & Unsupported \\
\hline H4 & RLA $\rightarrow$ CAD & -0.031 & 1.073 & 0.142 & Unsupported \\
\hline H5 & SEC $\rightarrow$ CAD & 0.180 & 4.557 & 0.000 & Supported \\
\hline H6 & TMS $\rightarrow$ CAD & 0.093 & 2.954 & 0.002 & Supported \\
\hline H7 & INP $\rightarrow$ CAD & 0.058 & 1.920 & 0.028 & Supported \\
\hline H8 & FR $\rightarrow$ CAD & 0.067 & 2.440 & 0.008 & Supported \\
\hline H9 & EEN $\rightarrow$ CAD & 0.132 & 4.292 & 0.000 & Supported \\
\hline H10 & COP $\rightarrow$ CAD & 0.114 & 3.595 & 0.000 & Supported \\
\hline H11 & CUP $\rightarrow$ CAD & 0.136 & 4.032 & 0.000 & Supported \\
\hline H12 & ATA $\rightarrow$ CAD & 0.174 & 4.571 & 0.000 & Supported \\
\hline H13 & INI $\rightarrow$ CAD & 0.172 & 4.328 & 0.000 & Supported \\
\hline H14 & INS $\rightarrow$ CAD & 0.080 & 2.059 & 0.020 & Supported \\
\hline
\end{tabular}

\section{FINDINGS AND DISCUSSION}

This study primarily aims to determine the impact of technological, organizational, environmental, and information culture factors on CRM adoption among Palestinian SMEs. The study findings provided descriptions of the exogenous variables-endogenous variables relationship, using the TOE framework, DOI, and RBV theories. Table 9 lists the tested hypotheses and the results.

Table 9: Summary of the Tested Hypothesis

\begin{tabular}{|c|c|c|}
\hline \multicolumn{2}{|r|}{ Hypothesis } & $\begin{array}{l}\text { Results and is consistent with previous } \\
\text { research findings }\end{array}$ \\
\hline $\mathrm{H} 1$ & $\begin{array}{l}\text { Compatibility } \rightarrow \text { CRM } \\
\text { adoption }\end{array}$ & $\begin{array}{l}\text { The hypothesis is supported }(\beta=0.114, \mathrm{t}=3.146 \text {, } \\
\mathrm{p}=0.001) \text {. These results are in line with } \\
\text { (Chavoshi et al., 2015; Meyliana \& Budiardjo, } \\
\text { 2016; Ahani et al., 2017). }\end{array}$ \\
\hline $\mathrm{H} 2$ & $\begin{array}{l}\text { IT infrastructure } \rightarrow \\
\text { CRM adoption }\end{array}$ & $\begin{array}{l}\text { The hypothesis is not supported }(\beta=0.027, \mathrm{t}= \\
0.869, \mathrm{p}=0.193) . \text { These results are in line with } \\
\text { (Coltman, Devinney, \& Midgley, 2011) }\end{array}$ \\
\hline
\end{tabular}




\begin{tabular}{|c|c|c|}
\hline \multicolumn{2}{|r|}{ Hypothesis } & \multirow{2}{*}{$\begin{array}{l}\text { Results and is consistent with previous } \\
\text { research findings } \\
\text { The hypothesis is not supported }(\beta=-0.027 \mathrm{t}= \\
0.732, \mathrm{p}=0.232 \text { ). These results are in line with } \\
\text { (Alhammadi et al., 2015; Ngah et al., 2014) }\end{array}$} \\
\hline H3 & $\begin{array}{l}\text { Complexity } \rightarrow \text { CRM } \\
\text { adoption }\end{array}$ & \\
\hline $\mathrm{H} 4$ & $\begin{array}{l}\text { Relative advantage } \rightarrow \\
\text { CRM adoption }\end{array}$ & $\begin{array}{l}\text { The hypothesis is not supported }(\beta=-0.031 \mathrm{t}= \\
1.073, \mathrm{p}=0.142) \text {. These results are in line with } \\
\text { (El-Gohary, 2012; Alhammadi et al., 2015) }\end{array}$ \\
\hline H5 & $\begin{array}{l}\text { Security } \rightarrow \text { CRM } \\
\text { adoption }\end{array}$ & $\begin{array}{l}\text { The hypothesis is supported }(\beta=0.180, t=4.557 \text {, } \\
p=0.000) . \text { These results are in line with (Koong, } \\
\text { Liu, Bai, \& Lin, 2008; T. K. Sin et al., 2009; Hua, } \\
\text { 2008) }\end{array}$ \\
\hline H6 & $\begin{array}{l}\text { Top management } \\
\text { support } \rightarrow \text { CRM adop- } \\
\text { tion }\end{array}$ & $\begin{array}{l}\text { The hypothesis is supported }(\beta=0.093, t=2.954, \\
p=0.002) . \text { These results are in line with (M. Muk- } \\
\text { red et al., 2018) }\end{array}$ \\
\hline $\mathrm{H} 7$ & $\begin{array}{l}\text { Information Poli- } \\
\text { cies } \rightarrow \text { CRM adoption }\end{array}$ & $\begin{array}{l}\text { The hypothesis is supported }(\beta=0.0058, \mathrm{t}=1.920 \text {, } \\
\mathrm{p}=0.028) . \text { These results are in line with (Mallett, } \\
\text { Nye, \& Sorrell, 2011; Raut et al., 2017) }\end{array}$ \\
\hline $\mathrm{H} 8$ & $\begin{array}{l}\text { Financial resources } \rightarrow \\
\text { CRM adoption }\end{array}$ & $\begin{array}{l}\text { The hypothesis is supported }(\beta=0.067, \mathrm{t}=2.440, \\
\mathrm{p}=0.008) . \text { These results are in line with } \\
\text { (Ghobakhloo et al., 2011; Sanjay, Mohapatra, \& } \\
\text { Anusree, 2013) }\end{array}$ \\
\hline H9 & $\begin{array}{l}\text { Employee engage- } \\
\text { ment } \rightarrow \text { CRM adop- } \\
\text { tion }\end{array}$ & $\begin{array}{l}\text { The hypothesis is supported }(\beta=0.131, \mathrm{t}=4.292 \text {, } \\
\mathrm{p}=0.000) . \text { These results are in line with (Ernst, } \\
\text { Hoyer, Krafft, \& Krieger, 2011; Sultan et al., } \\
\text { 2018) }\end{array}$ \\
\hline H10 & $\begin{array}{l}\text { Competitive pres- } \\
\text { sure } \rightarrow \text { CRM adoption }\end{array}$ & $\begin{array}{l}\text { The hypothesis is supported }(\beta=0.114, t=3.595 \\
\mathrm{p}=0.000) . \text { These results are in line with (Oliveira } \\
\& \text { Martins, 2010; K. Y. Sin et al., 2016; Wang, Li, } \\
\text { Li, \& Zhang, 2016) }\end{array}$ \\
\hline H11 & $\begin{array}{l}\text { Customers pressure } \rightarrow \\
\text { CRM adoption }\end{array}$ & $\begin{array}{l}\text { The hypothesis is supported }(\beta=0.136, t=4.032 \text {, } \\
p=0.000) . \text { These results are in line } \\
\text { (Sophonthummapharn, 2009; Maduku et al., } \\
\text { 2016) }\end{array}$ \\
\hline H12 & $\begin{array}{l}\text { Attitude toward adop- } \\
\text { tion tech } \rightarrow \text { CRM } \\
\text { adoption }\end{array}$ & $\begin{array}{l}\text { The hypothesis is supported }(\beta=0.174, \mathrm{t}=4.571 \text {, } \\
\mathrm{p}=0.000) . \text { These results are in line with (Ramayah } \\
\text { et al., 2016; Alharbi, Atkins, \& Stanier, 2016) }\end{array}$ \\
\hline H13 & $\begin{array}{l}\text { information integri- } \\
\text { ty } \rightarrow \text { CRM adoption }\end{array}$ & $\begin{array}{l}\text { The hypothesis is supported by } \beta=0.172, \mathrm{t}= \\
4.328, \mathrm{p}=0.000) . \text { These results are in line with } \\
\text { (Furness, 2010; Choo, 2013) }\end{array}$ \\
\hline H14 & $\begin{array}{l}\text { Information sharing } \rightarrow \\
\text { CRM adoption }\end{array}$ & $\begin{array}{l}\text { The hypothesis is supported }(\beta=0.080, t=2.059 \text {, } \\
p=0.020) \text {. These results are in line with (Choo et } \\
\text { al., 2008; Brockman et al., 2017) }\end{array}$ \\
\hline
\end{tabular}

\section{Compatibility}

The results confirmed H1, which stated that compatibility has a positive effect on CRM adoption by Palestinian SMEs. Compatibility is the top significant direct effect on behavioral intention towards 
using CRM technology (Alweshah, Almanasrah, \& Alqatawneh, 2018). Several studies have been describing the role of compatibility in determining the adoption of IT innovation (Ahani et al., 2017). Compatibility reflects the level to which CRM has aligned with the organization's past experiences and current needs (Chavoshi et al., 2015). Consequently, it is essential for SMEs that the new innovation is consistent with their existing values and needs (Alshamaila et al., 2013).

\section{Security}

The results confirmed H5, which stated that security has a positive effect on CRM adoption by Palestinian SMEs. This empirical finding is aligned with the findings reported by other scholars who found the lack of security as one of the several barriers to the IS system (Awa et al., 2016; T. K. Sin et al., 2009). Security is challenging research areas that have been largely ignored in the majority of CRM techniques (Soltani \& Navimipour, 2016). Moreover, lack of security perceived by e-commerce customers is a topmost barrier in developing countries (Ghobakhloo \& Tang, 2013). In a related study, AlMabhouh and Alzaza (2015) revealed that security is the most obstacles in Palestinian organizations and should take into consideration.

\section{Top management support}

Hypotonia 6, that top management support has a positive effect on CRM adoption by Palestinian SMEs. This was also indicated by other studies that examined the effect of top management support as among the critical factors influencing new technologies adoption (M. Mukred et al., 2018); Ahani et al., 2017). The higher the top management support, the smoother will be the adoption and the overcoming of difficulties faced during such adoption (Salah, 2018b). This finding is in line with Herzallah \& Mukhtar (2015) who revealed that top management support has a positive effect on the success of EC adoption within SMEs in Palestine. Top management support has a crucial role in decision making and in setting a bar for training staff to enhance their skills, which in turn affects the company successes. Without management support, CRM adoption efforts will be for nothing.

\section{Information policies}

The results confirmed H7, which stated that Information Policies have a positive effect on CRM adoption by Palestinian SMEs. Lack of information or inaccurate information is one of the most critical hindrances in adopting technology in developing nations (Mallett et al., 2011). The 'information policies' control communication technologies regulation, and as such, policies are significant elements in the discussion of information culture (Riyaz, 2009). Respondents to the survey considered Information Policies as one of the factors that work towards improving the adoption of CRM among SMEs. Lack of information or inaccurate information is one of the hindrances of adopting CRM technology in SMEs.

\section{Financial resources}

In regard to $\mathrm{H} 8$, this study showed that financial resources have a positive effect on CRM adoption by Palestinian SMEs. The successful adoption of new technology requires financial investments for installment, training, enhancement, and customization (Hasani et al., 2017). On the other hand, lack of financial resources may consequently result in ineffective business research (Sanjay et al., 2013). Limited financial resources force owners/managers to be careful when adopting technology, and as such, this is the reason why small businesses mostly lack funds to adopt IS (Ghobakhloo \& Tang, 2013). In the context of Egypt, university libraries face barriers relating to lack of 'financial resources' for CRM and lack of software and technologies that facilitate CRM management (Fouad \& Al-Goblan, 2017). In Palestinian context, financial cost influences the behavioral intention of Higher Educational Institutions to adopt CRM technology (Badwan, Al-Shobaki, Abu Naser, \& Abu Amuna, 2017). 


\section{Employee engagement}

Hypothesis 9, this study showed employee engagement has a positive effect on CRM adoption by Palestinian SMEs. CRM adoption initiative may fail when there are only a few committed employees to it, and thus, employee engagement has become essential issues in CRM (Sultan et al., 2018). Employee engagement is a significant predictor of positive organization performance; evidence has shown that a two-way relationship between employer and employee, even stronger than job satisfaction and employee commitment (Markos \& Sandhya, 2010). This finding is in line with prior research Sultan et al. (2018) and Ernst et al. (2011), who revealed that potential CRM failure arises when there are only a few committed employees to the initiative. Employee engagement facilitates the discussion and addressing of CRM issues. This is in line with the respondents, who indicate that employee engagement affects business results and, eventually, increases the possibility of acquiring a competitive advantage. They stressed that CRM technology initiatives might fail if only a few employees are committed to it.

\section{Competitive pressure}

The results confirmed H10, which stated that competitive pressure has a positive effect on CRM adoption by Palestinian SMEs. This finding is consistent with Alshawi et al., (2011). 'Competitive pressure' is one of the main reasons for investing in CRM, and this is particularly true if CRM is viewed as an asset that allows organizations to increasingly focus on their customers (Iriana et al., 2013). Competitive put pressure on the organization to be more creative and forces its leaders to adopt strategies to increase market share (Beglari, 2017). In the Palestinian context, if a competitor begins using any innovation, the company should find a strong push towards the adoption of this innovation in order to achieve competitive advantages (Qashou \& Saleh, 2018).

\section{Customer pressure}

The results confirmed H10, which stated that customer pressure has a positive effect on CRM adoption by Palestinian SMEs. Studies have evidenced the customer pressure-adoption decision relationship among firms (Alrousan \& Jones, 2016; Hoti, 2015; Ngah et al., 2014). In the context of Palestine. SMEs should adopt a specific IT because of the pressure from its customers in different fields, such as E-marketing acceptance and implementation (Qashou \& Saleh, 2018). This is proven when Gualandris and Kalchschmidt (2014) revealed that 'customer pressure' is a top determinant of the Firm's Environmental Performance. It even has a significant effect on green innovation adoption among SMEs (Piaralal et al., 2015; Ngah et al., 2017).

\section{Attitude toward technology adoption}

The results confirmed H12, which stated that Attitude toward technology adoption has a positive effect on CRM adoption by Palestinian SMEs. In related studies, attitude toward IT adoption is one of the top drivers of technology adoption and organization extension (Ramayah et al., 2016; Alharbi et al., 2016). Moreover, CRM system effectiveness needs employees to have the right attitude and behavior; otherwise, Failed CRM adoption, which can be of immediacy (Chavoshi et al., 2015).

Newby, Nguyen, and Waring (2014) indicate that managers who have a positive attitude towards IT are more likely to be successful in adopting new technology. In SME, employees attitude towards adopting IT has a significant effect on Technology Acceptance and a successful adoption (Ghobakhloo et al., 2011). This was supported by Shraim and Crompton (2015) who stated that displaying a positive attitude towards using IT has a direct effect towards mobile technology in higher education in Palestine.

\section{Information integrity}

The results confirmed H13, which stated that Information integrity has a positive effect on CRM adoption by Palestinian SMEs. In relation to this, information integrity is a necessity for organization 
managers and leaders (Furness, 2010) as it sets up boundaries for workers and establishes how they can use information in a suitable and sanctioned manner (Choo, 2013). In the context of Palestine, Herzallah and Mukhtar (2015) information integrity implying that it is a desired trait in managers and people in decision- making positions. Information Integrity in the initiative of information management as it facilitates accurate and formal information about the performance (individual and enterprise) of employees.

\section{Information sharing}

The results confirmed H14, which stated that Information sharing has a positive effect on CRM adoption by Palestinian SMEs. In a small organizational unit, information sharing is significant in light of job satisfaction and higher self-reported performance compared to frequent and general contacts with environments characterized by rich information (Lauri et al., 2016). Within the CRM context, communication sharing is entailed between business and customers (Trainor, 2012). It forms one of the fundamental CRM functions, but the roles and expectations specified in the contract may limit the sharing of in-depth information in supplier-customer relationships (P. Williams et al., 2017). Respondents' opinions supported the result and revealed that having positive Information Sharing affects the adoption of CRM technology directly.

There are also other variables that have an insignificant relationship with the intention of CRM adoption among Palestinian SMEs. For instance, complexity (H3) has an insignificant positive effect on CRM adoption, a result that is consistent with those reported by Alhammadi et al. (2015) and Ngah et al. (2014), but is inconsistent with that by Ahmad et al. (2015), who found a significant relationship between complexity in different fields (e.g., e-commerce adoption). Relative advantage (H4) also has an insignificant direct effect on the adoption of CRM, a result which is consistent with those reported by some studies (Alhammadi et al., 2015; El-Gohary, 2012) but inconsistent with others like that of Alshamaila et al. (2013) who found relative advantage to have top effect on innovation adoption. This also held true for the findings of Chiu et al. (2017). Moreover, many studies emphasize that the IT infrastructure (H2) forms the core of business operations such as CRM (Alshamaila et al., 2013; Kumar \& Reinarzt, 2012; G. Kim, Shin, Kim, \& Lee, 2011). In this study, the results support the insignificant influence of IT infrastructure, and this is line with the findings of Coltman et al. (2011) that revealed no significant direct effect of IT infrastructure on optimum CRM capability. The insignificant relationship may be attributed to the respondents in this study, who had technical backgrounds and may have had self-efficacy when using technology and thus the IT infrastructure, complexity, and relative advantage level in determining their behavioral intention have been mitigated

To sum up, In the present study, the insignificant relationship between may be attributed to the respondents in this study, who had technical backgrounds and may have had self-efficacy when using technology and thus the complexity level in determining their behavioral intention has been mitigated (Alhammadi et al., 2015). The recommendation from Palestinian SMEs confirmed the extensive accuracy of the proposed framework based on four major contexts (technological, organizational, environmental, and information culture) that drive the adoption and intention to adopt CRM among SMEs employees. The Palestinian SMEs also confirmed that the framework contains the top significant factors that influence such adoption, as evidenced by frequent attempts of enterprises to acquire competitive advantage through customer relationships. This calls for effective planning and communication via CRM to adapt to the changes in the market.

\section{CONCLUSION}

CRM technology has become invaluable for businesses in seeking increased revenues and maintaining performance. It allows firms to keep abreast of issues faced by customers, oversee service response, and respond to customer inquiries appropriately. Although CRM has gained significant attention, it still suffers from conceptual and methodological flaws. Moreover, studies dedicated to the relationship of CRM in this context are still scarce. CRM studies have been carried out focusing on 
major firms, with only a few tackling CRM adoption among SMEs. Thus, this study attempted to examine the success factors affecting CRM adoption among SMEs in Palestine and the interconnections among them. The findings show that compatibility, security, top management support, employee engagement, information policies, financial resource, customer pressure, competitive pressure, attitude toward technology adoption, information sharing, and information integrity are all significantly related to intention toward CRM adoption, while IT infrastructure, complexity, and relative advantage have no significant relation. Moreover, this study contributes to both academics and business practitioners by providing insights into factors that affect CRM adoption in Palestinian SMEs, which did not explore before. This is the first study in Palestine, which will provide policymakers and top-level managers of SMEs to structure their activities in relation to CRM adoption based on the level of the factors examined. The findings of this study are limited to generalization toward Palestinian SMEs, and those neighboring countries similar to Palestine in culture and situation. The study, however, fell short of covering all the SME industry groups in Palestine. Thus, Future studies may examine the effect of CRM technology in different industries, sectors, and economies.

\section{ACKNOWLEDGMENT}

The study is financially supported by Research Grant GUP-2017-046, Universiti Kebangsaan Malaysia, and the Public Services Department of Malaysia.

\section{REFERENCES}

Abou-Shouk, M. A., Lim, W. M., \& Megicks, P. (2016). Using competing models to evaluate the role of environmental pressures in ecommerce adoption by small and medium sized travel agents in a developing country. Tourism Management, 52, 327-39. https://doi.org/10.1016/j.tourman.2015.07.007

Abrahamson, D. E., \& Goodman-Delahunty, J. (2013). The impact of organizational information culture on information use outcomes in policing: an exploratory study. Information Research, 18(4), 1-28. Retrieved from https://researchoutput.csu.edu.au/ws/portalfiles/portal/8875795/51851 Abrahamson_PUB.pdf

AbuShanab, E., Pearson, J. M., \& Setterstrom, A. J. (2010). Internet banking and customers' acceptance in Jordan: The unified model's perspective. Communications of the Association for Information Systems, 26(1), 23. https://doi.org/10.17705/1CAIS.02623

Ahani, A., Rahim, N. Z. A., \& Nilashi, M. (2017, July). Firm performance through social customer relationship management: Evidence from small and medium enterprises. 2017 International Conference on Research and Innovation in Information Systems (ICRIIS) (pp. 1-6). IEEE. https:// doi.org/10.1109/ICRIIS.2017.8002533

Ahearne, M., Rapp, A., Mariadoss, B. J., \& Ganesan, S. (2012). Challenges of CRM implementation in businessto-business markets: A contingency perspective. Journal of Personal Selling \& Sales Management, 32(1), 117129. https://doi.org/10.2753/PSS0885-3134320110

Ahmad, S. Z., Abu ,B. A. R., Faziharudean, T. M., \& Mohamad, Z. K. A. (2015). An empirical study of factors affecting e-commerce adoption among small-and medium-sized enterprises in a developing country: Evidence from Malaysia. Information Technology for Development, 21(4), 555-572. https://doi.org/10.1080/02681102.2014.899961

Al-Ansari, Y., Pervan, S., \& Xu, J. (2013). Innovation and business performance of SMEs: The case of Dubai. Education, Business and Society: Contemporary Middle Eastern Issues, 6(3/4), 162-180. https://doi.org/10.1108/EBS-04-2013-0012

Al-Duwailah, F., \& Ali, M. (2013). The effect of organizational culture on CRM success. 2013 European, Mediterranean \& Middle Eastern Conference on Information Systems (EMCIS2013), Windsor, United Kingdom (pp. 1-12). Retrieved from https://bura.brunel.ac.uk/bitstream/2438/8185/2/Fulltext.pdf

Alfoqahaa, S. (2018). Critical success factors of small and medium-sized enterprises in Palestine. Journal of Research in Marketing and Entrepreneurship, 20(2), 170-188. https://doi.org/10.1108/JRME-05-2016-0014 
Alhammadi, A., Stanier, C., \& Eardley, A. (2015). The determinants of cloud computing adoption in Saudi Arabia. Computer Science \& Information Technology (CS \& IT), 5, 55-67. https://doi.org/10.5121/csit.2015.51406

Alharbi, F., Atkins, A., \& Stanier, C. (2016). Understanding the determinants of Cloud Computing adoption in Saudi healthcare organisations. Complex \& Intelligent Systems, 2(3), 155-171. https://doi.org/10.1007/s40747-016-0021-9

Alkhatib, A. A., Abdul-Jabbar, H., \& Marimuthu, M. (2018). The effects of deterrence factors on income tax evasion among Palestinian SMEs. International Journal of Academic Research in Accounting, Finance and Management Sciences, 8(4), 144-152. Retrieved from http://hrmars.com/hrmars papers/The Effects of Deterrence Factors on Income Tax Evasion amo ng Palestinian SMEs.pdf

Alkhazali, A. R., \& Hassan, S. (2015). The effect of customer relationship management system adoption and perception on organization performance: Study of Jordanian hospital sectors. Journal of Management and Sustainability, 5(4), 141-146. https://doi.org/10.5539/jms.v5n4p141

AlMabhouh, A., \& Alzaza, N. S. (2015). Barriers for adoption of Cloud Computing in the Palestinian industries. European Journal of Computer Science and Information Technology, 3(4), 43-57. Retrieved from https://www.eajournals.org/journals/european-journal-of-computer-science-and-information-technologyejcsit/vol-3issue-4-august-2015/barriers-for-adoption-of-cloud-computing-in-the-palestinian-industries/

Alrousan, M. K., \& Jones, E. (2016). A conceptual model of factors affecting e-commerce adoption by SME owner/managers in Jordan. International Journal Business Information Systems, 21(3), 269-308. https://doi.org/10.1504/IJBIS.2016.074762

Alshamaila, Y., Papagiannidis, S., \& Li, F. (2013). Cloud computing adoption by SMEs in the north east of England: A multi-perspective framework. Journal of Enterprise Information Management, 26(3), 250-275. https://doi.org/10.1108/17410391311325225

Alshawi, S., Missi, F., \& Irani, Z. (2011). Organisational, technical and data quality factors in CRM adoption SMEs perspective. Industrial Marketing Management, 40(3), 376-383. https://doi.org/10.1016/j.indmarman.2010.08.006

Alweshah, G. A., Almanasrah, E., \& Alqatawneh, M. (2018). Customer relationship management systems and organizational performance: Quantitative evidence from the Jordanian telecommunication industry. Journal of Marketing Communications 25(8), 799-819. https://doi.org/10.1080/13527266.2018.1449007

Atout, A. (2015). Determinants of small business lending in Palestine. Doctoral Dissertation. Gazimağusa, North Cyprus: Eastern Mediterranean University (EMU)-Doğu Akdeniz Üniversitesi (DAÜ). Retrieved from http://i-rep.emu.edu.tr:8080/jspui/bitstream/11129/1772/1/AtoutAbdalmalek.pdf

Awa, H. O., Ukoha, O., \& Emecheta, B. C. (2016). Using TOE theoretical framework to study the adoption of ERP solution. Cogent Business \& Management, 3(1), 1-23. https://doi.org/10.1080/23311975.2016.1196571

Azadegan, A., \& Teich, J. (2010). Effective benchmarking of innovation adoptions. Benchmarking: An International Journal, 17(4), 472-490. https://doi.org/10.1108/14635771011060558

Badwan, J., Al Shobaki, M., Abu Naser, S., \& Abu Amuna, Y. (2017). Adopting technology for customer relationship management in higher educational institutions. International Journal of Engineering and Information Systems (IJEAIS), 1(1), 20-28. https://doi.org/hal.archives-ouvertes.fr/hal-01500365

Baidoun, S. D., Lussier, R. N., Burbar, M., \& Awashra, S. (2018). Prediction model of business success or failure for Palestinian small enterprises in the West Bank. Journal of Entrepreneurship in Emerging Economies, 10(1), 60-80. https://doi.org/10.1108/JEEE-02-2017-0013

Barney, J. B., \& Arikan, A. M. (2001). The resource-based view: Origins and implications. In M. A. Hitt, R. E. Freeman, \& J. S. Harrison (Eds.). The Blackwell handbook of strategic management (pp. 123-182). https://doi.org/10.1111/b.9780631218616.2006.00006.x

Beglari, S. (2017). Effective competitive strategies of U.S. in vitro device manufacturers. Published PhD thesis. Walden University. Retrieved from http:/ / scholarworks.waldenu.edu/cgi/viewcontent.cgi?article $=5373 \&$ context $=$ dissertations 
CRM Initiative among Palestinian Enterprises

Berisha, G., \& Pula, J. S. (2015). Defining small and medium enterprises: A critical review. Academic Journal of Business, Administration, Law and Social Sciences, 1(1), 17-28. Retrieved from http://iipccl.org/wpcontent/uploads/2015/03/Ajbals-17-28.pdf

Brockman, B. K., Park, J. E., \& Morgan, R. M. (2017). The role of buyer trust in outsourced CRM: Its influence on organizational learning and performance. Journal of Business-to-Business Marketing, 24(3), 201-219. https://doi.org/10.1080/1051712X.2017.1345260

Carr, A. S., \& Pearson, J. N. (1999). Strategically managed buyer-supplier relationships and performance outcomes. Journal of Operations Management, 17(5), 497-519. https://doi.org/10.1016/S0272-6963(99)00007-8

Chao, C. A., \& Chandra, A. (2012). Impact of owner's knowledge of information technology (IT) on strategic alignment and IT adoption in US small firms. Journal of Small Business and Enterprise Development, 19(1), 114131. https://doi.org/10.1108/14626001211196433

Chavoshi, M., Sim, A. T. H., \& Hee, J. M. (2015). A CRM adoption model for Malaysian telecommunication and finance companies. Journal of Information Systems Research and Innovation, 9(2), 119-125. Retrieved from https://seminar.spaceutm.edu.my/jisri/download/F FinalPublished/Pub15 CRMModel TelcoAndFinan cial amend.pdf

Chen, X. (2012). Impact of business intelligence and IT infrastructure flexibility on competitive advantage: An organizational agility perspective. Doctoral Dissertation. Lincoln, Nebraska: University of Nebraska. Retrieved from https:/ / digitalcommons.unl.edu/cgi/viewcontent.cgi?article $=1036 \&$ context $=$ businessdiss

Chien, T. K., Ma, H. Y., \& Hou, K. L. (2015, December). A study for establishing ideal crm system function structure. In 2015 IEEE International Conference on Industrial Engineering and Engineering Management (IEEM) (pp. 681-685). IEEE. https://doi.org/10.1109/IEEM.2015.7385734

Chiles, E. (2015). Expectations of job satisfaction based on three common leadership styles. Doctoral Dissertation. Minneapolis, Minnesota: Walden University. Retrieved from https://scholarworks.waldenu.edu/cgi/viewcontent.cgi?article $=1458 \&$ context $=$ dissertations

Chin, W. W., \& Newsted, P. R. (1999). Structural equation modeling analysis with small samples using partial least squares. Statistical Strategies for Small Sample Research, 1(1), 307-341.

Ching, H. L., \& Ellis, P. (2004). Marketing in cyberspace: What factors drive e-commerce adoption?. Journal of Marketing Management, 20(3-4), 409-429. https://doi.org/10.1362/026725704323080470

Chiu, C. Y., Chen, S., \& Chen, C. L. (2017). An integrated perspective of TOE framework and innovation diffusion in broadband mobile applications adoption by enterprises. International Journal of Management, Economics and Social Sciences (IJMESS), 6(1), 14-39. Retrieved from https://www.econstor.eu/bitstream/10419/157921/1/886618134.pdf

Choo, C. W. (2013). Information culture and organizational effectiveness. International Journal of Information Management, 33(5), 775-779. https://doi.org/10.1016/j.ijinfomgt.2013.05.009

Choo, C. W., Bergeron, P., Detlor, B., \& Heaton, L. (2008). Information culture and information use: An exploratory study of three organizations. Journal of the American Society for Information Science and Technology, 59(5), 792-804. https://doi.org/10.1002/asi.20797

Chuang, T. T., Nakatani, K., \& Zhou, D. (2009). An exploratory study of the extent of information technology adoption in SMEs: An application of upper echelon theory. Journal of Enterprise Information Management, 22(1/2), 183-196. https://doi.org/10.1108/MRR-09-2015-0216

Coltman, T., Devinney, T. M., \& Midgley, D. F. (2011). Customer relationship management and firm performance. Journal of Information Technology, 26(3), 205-219. https://doi.org/10.1057/jit.2010.39

Custom Insight. (2019). Employee engagement survey sample - Example questions of employee satisfaction surveys. Retrieved from https://www.custominsight.com/employee-engagement-survey/sample-survey-items.asp

Davis, F. D. (1989). Perceived usefulness, perceived ease of use, and user acceptance of information technology. MIS Quarterly, 13(3), 319-340. https://doi.org/10.2307/249008 
Eid, R., \& El-Gohary, H. (2014). Testing and validating customer relationship management implementation constructs in Egyptian tourism organizations. Journal of Travel \& Tourism Marketing, 31(3), 344-365. https://doi.org/10.1080/10548408.2014.883348

El-Gohary, H. (2012). Factors affecting e-Marketing adoption and implementation in tourism firms: An empirical investigation of Egyptian small tourism organisations. Tourism Management, 33(5), 1256-1269. https://doi.org/10.1016/j.tourman.2011.10.013

Ernst, H., Hoyer, W. D., Krafft, M., \& Krieger, K. (2011). Customer relationship management and company performance - The mediating role of new product performance. Journal of the Academy of Marketing Science, 39(2), 290-306. https://doi.org/10.1007/s11747-010-0194-5

Fouad, N. \& Al-Goblan, N. (2017). Using customer relationship management systems at university libraries. IFL A Journal, 43(2), 158-170. https://doi.org/10.1177/0340035216685103

Fornell, C., \& Larcker, D. F. (1981). Evaluating structural equation models with unobservable variables and measurement error. Journal of Marketing Research, 18(1), 39-50. https://doi.org/10.1177/002224378101800104

Frygell, L., Hedman, J., \& Carlsson, S. (2017, January). Implementing CRM system in a global organizationnational vs. organizational culture. In Proceedings of the 50th Hawaii International Conference on System Sciences (pp. 4586-4595). https://doi.org/10.24251/HICSS.2017.553

Furness, C. D. (2010). Group information behavioural norms and the effective use of a collaborative information system: A case study. Doctoral Thesis. Toronto, Canada: University of Toronto. Retrieved from https://www.researchgate.net/profile/Colin Furness/publication/266469083 Group Information Beha viour-

al Norms and the Effective Use of a Collaborative Information System A Case Study/links/54352 bf50cf2dc341daf99fb.pdf

Garrido-Moreno, A., \& Padilla-Meléndez, A. (2011). Analyzing the impact of knowledge management on CRM success: The mediating effects of organizational factors. International Journal of Information Management, 31(5), 437-444. https://doi.org/10.1016/j.ijinfomgt.2011.01.002

Ghalenooie, M. B., \& Sarvestani, H. K. (2016). Evaluating human factors in customer relationship management case study: Private banks of Shiraz city. Procedia Economics and Finance, 36, 363-373. https://doi.org/10.1016/S2212-5671(16)30048-X

Ghobakhloo, M., Sabouri, M. S., Tang. S. H., \& Zulkifli, N. (2011). Information technology adoption in small and medium-sized enterprises: An appraisal of two decades literature. Interdisciplinary Journal of Research in Business, 1(7), 53-80.

Ghobakhloo, M., \& Tang, S. H. (2013). The role of owner/manager in adoption of electronic commerce in small businesses: The case of developing countries. Journal of Small Business and Enterprise Development, 20(4), 754-787. https://doi.org/10.1108/JSBED-12-2011-0037

Ghobakhloo, M., Tang. S. H., Sabouri, M. S., \& Zulkifli, N. (2012). Strategies for successful information technology adoption in small and medium-sized enterprises. Information, 3(4), 36-67. https://doi.org/10.3390/info3010036

Grassian, E., Mizrachi, D., Roy, L., \& Kos, D. (2015). The Third European Conference on Information Literacy (ECIL) October 19-22, 2015, Tallinn, Estonia. Retrieved from https://www.researchgate.net/profile/Sirje Virkus/publication/283546728 The Third European Confe rence on Information Literacy ECIL/links/563e2aa008ae8d65c0142f13.pdf

Grover, V., \& Goslar, M. D. (1993). The initiation, adoption, and implementation of telecommunications technologies in US organizations. Journal of Management Information Systems, 10(1), 141-164. https://doi.org/10.1080/07421222.1993.11517994

Gualandris, J., \& Kalchschmidt, M. (2014). Customer pressure and innovativeness: Their role in sustainable supply chain management. Journal of Purchasing and Supply Management, 20(2), 92-103. https://doi.org/10.1016/j.pursup.2014.03.001 
CRM Initiative among Palestinian Enterprises

Hair, J. F., Black, W., Babin, B., \& Anderson, R. (2014). Multivariate data analysis (7th ed.). UK: Pearson Education Limited. Retrieved from https://is.muni.cz/el/1423/podzim2017/PSY028/um/ Hair Multivariate data analysis 7 th revised.pdf

Hair, J. F., Hult, G. T. M., Ringle, C. M., Sarstedt, M., \& Thiele, K. O. (2017). Mirror, mirror on the wall: A comparative evaluation of composite-based structural equation modeling methods. Journal of the Academy of Marketing Science, 45(5), 616-632. https://doi.org/10.1007/s11747-017-0517-x

Hair, J. F., Hult, G. T. M., Ringle, C., \& Sarstedt, M. (2016). A primer on partial least squares structural equation modeling (PLS-SEM). Thousand Oaks, California: Sage Publications.

Hair, J. F., Ringle, C. M., \& Sarstedt, M. (2013). Partial least squares structural equation modeling: Rigorous applications, better results and higher acceptance. Long Range Planning, 46(1-2), 1-12. https://doi.org/10.1016/j.lrp.2013.01.001

Hair, J. F., Sarstedt, M., Hopkins, H., \& Kuppelwieser, V. (2014). Partial least squares structural equation modeling (Pls-Sem ). An emerging tool in business research. European Business Review, 26(2), 106-121. https://doi.org/10.1108/EBR-10-2013-0128

Harrigan, P., Ramsey, E., \& Ibbotson, P. (2012). Exploring and explaining SME marketing: Investigating e-CRM using a mixed methods approach. Journal of Strategic Marketing, 20(2), 127-163. https://doi.org/10.1080/0965254X.2011.606911

Harter, J. K., Schmidt, F. L., \& Hayes, T. L. (2002). Business-unit-level relationship between employee satisfaction, employee engagement, and business outcomes: A meta-analysis. Journal of Applied Psychology, 87(2), 268-279. https://doi.org/10.1037/0021-9010.87.2.268

Hasani, T., Bojei, J., \& Dehghantanha, A. (2017). Investigating the antecedents to the adoption of SCRM technologies by start-up companies. Telematics and Informatics, 34(5), 655-675. https://doi.org/10.1016/j.tele.2016.12.004

Henseler, J., Ringle, M. C., \& Sinkovics, R. R. (2009). The use of partial least squares path modeling in international marketing. International Marketing, 20(1), 277-319. https://doi.org 10.1108/S1474$\underline{7979(2009) 0000020014}$

Herzallah, F., \& Mukhtar, M. (2015). The impact of internal organization factors on the adoption of ecommerce and its effect on organizational performance among Palestinian small and medium enterprise. International Conference on E- Commerce, pp. 104-111. Retrieved from https://pdfs.semanticscholar.org/17ef/9824bf09c7c714de11b77d9260f28440a84a.pdf

Hoti, E. (2015). The technological, organizational and environmental framework of IS innovation adaption in small and medium enterprises. Evidence from research over the last 10 years. International Journal of Business and Management, 3(4), 1-14. https://doi.org/10.20472/BM.2015.3.4.001

Hua, G. (2008). An experimental investigation of online banking adoption in China. AMCIS 2008 Proceedings, 36. Retrieved from http://www.icommercecentral.com/open-access/an-experimental-investigation-ofonline-banking-adoption-in-china.php?aid $=38321$

Iriana, R., Buttle, F., \& Ang, L. (2013). Does organisational culture influence CRM's financial outcomes? Journal of Marketing Management, 29(3-4), 467-493. https://doi.org/10.1080/0267257X.2012.732598

Izogo, E. E., \& Ogba, I. E. (2015). Service quality, customer satisfaction and loyalty in automobile repair services sector. International Journal of Quality \& Reliability Management, 32(3), 250-269. https://doi.org/10.1108/IJQRM-05-2013-0075

Jaber, F. N., \& Simkin, L. (2017). Understanding customer relationship management (CRM) adoption in an Arab Middle Eastern context. Behaviour \& Information Technology, 36(10), 1020-1036. https://doi.org/10.1080/0144929X.2017.1332098

Kangu, M. A. (2017). The role of customer relationship management dimensions on customer loyalty in the botel industry in Kenya. Doctoral Dissertation. Juja, Kenya: Jomo Kenyatta University of Agriculture \& Technology (JKUAT). Retrieved from http://ir.jkuat.ac.ke/bitstream/handle/123456789/3191/Maureen\%20Kangu\%20PhD\%20Thesis\%2026t $\underline{\mathrm{h} \% 20 \mathrm{May} \% 202017 . \mathrm{pdf}}$ 
Keramati, A., Mehrabi, H., \& Mojir, N. (2010). A process-oriented perspective on customer relationship management and organizational performance: An empirical investigation. Industrial Marketing Management, 39(7), 1170-1185. https://doi.org/10.1016/j.indmarman.2010.02.001

Kim, C., Lee, I. S., Wang, T., \& Mirusmonov, M. (2015). Evaluating effects of mobile CRM on employees’ performance. Industrial Management \& Data Systems, 115(4), 740-764. https://doi.org/10.1108/IMDS-08-2014$\underline{0245}$

Kim, G., Shin, B., Kim, K. K., \& Lee, H. G. (2011). IT capabilities, process-oriented dynamic capabilities, and firm financial performance. Journal of the Association for Information Systems, 12(7), 487. https://doi.org/10.17705/1jais.00270

Koong, K. S., Liu, L. C., Bai, S., \& Lin, B. (2008). Identity theft in the USA: Evidence from 2002 to 2006. International Journal of Mobile Communications, 6(2), 199-216. https://doi.org/10.1504/IJMC.2008.016577

Kumar, V., \& Reinartz, W. (2012). Strategic customer relationship management today. In V. Kumar \& W. Reinartz, Customer relationship management (pp. 3-20). Springer Texts in Business and Economics. Berlin, Germany: Springer Heidelberg https://doi.org/10.1007/978-3-642-20110-3 1

Laan, S. (2013). IT infrastructure architecture - Infrastructure building blocks and concepts (2nd ed.). Morrisville, North Carolina: Lulu Press Inc.

Lai, H. M., Lin, I. C., \& Tseng, L. T. (2014). High-level managers' considerations for RFID adoption in hospitals: an empirical study in Taiwan. Journal of Medical Systems, 38(3). https://doi.org/10.1007/s10916-0130003-z

Laketa, M., Sanader, D., Laketa, L., \& Misic, Z. (2015). Customer relationship management: Concept and importance for banking sector. UTMS Journal of Economics, 6(2), 241-254. Retrieved from https://www.econstor.eu/bitstream/10419/146362/1/857644092.pdf

Lauri, L., Heidmets, M., \& Virkus, S. (2016). The information culture of higher education institutions: The Estonian case. Information Research: An International Electronic Journal, 21(3), n3. Retrieved from https:// files.eric.ed.gov/fulltext/EJ1114153.pdf

Law, R., Fong, D. K. C., Chan, I. C. C., \& Fong, L. H. N. (2018). Systematic review of hospitality CRM research. International Journal of Contemporary Hospitality Management, 30(3), 1686-1704. https://doi.org/10.1108/IJCHM-06-2017-0333

Lee, Y. C., Tang, N. H., \& Sugumaran, V. (2014). Open source CRM software selection using the analytic hierarchy process. Information Systems Management, 31(1), 2-20. https://doi.org/10.1080/10580530.2013.854020

Li, E. Y., \& Shani, A. B. (1991). Stress dynamics of information systems managers: A contingency model. Journal of Management Information Systems, 7(4), 107-130. https://doi.org/10.1080/07421222.1991.11517906

Li, L., \& Mao, J. Y. (2012). The effect of CRM use on internal sales management control: An alternative mechanism to realize CRM benefits. Information \& Management, 49(6), 269-277. https://doi.org/10.1016/j.im.2012.09.005

Li, Y. H. (2008, September). An empirical investigation on the determinants of e-procurement adoption in Chinese manufacturing enterprises. In Proceedings of the 15th Annual International Conference on Management Science and Engineering, ICMSE2008 (pp. 32-37). IEEE. https://doi.org/10.1109/ICMSE.2008.4668890

Liu, W., \& Atuahene-Gima, K. (2018). Enhancing product innovation performance in a dysfunctional competitive environment: The roles of competitive strategies and market-based assets. Industrial Marketing Management, 73, 7-20. https://doi.org/10.1016/j.indmarman.2018.01.006

Maduku, D. K., Mpinganjira, M., \& Duh, H. (2016). Understanding mobile marketing adoption intention by South African SMEs: A multi-perspective framework. International Journal of Information Management, 36(5), 711-723. https://doi.org/10.1016/i.iiinfomgt.2016.04.018

Mallett, A., Nye, S., \& Sorrell, S. (2011). Policy options to overcome barriers to industrial energy efficiency in developing countries. Development Policy, Statistics and Research Branch (Working Paper 13/2011). Vienna, Austria: United Nations Industrial Development Organization. Retrieved from http://sro.sussex.ac.uk/id/eprint/53956/1/WP132011 Policy Options to Overcome Barriers to Indu strial Energy Efficiency in Developing Countries.pdf 
CRM Initiative among Palestinian Enterprises

Markos, S., \& Sandhya, S. (2010). Employee engagement: The key to improving performance. International Journal of Business and Management, 5(12), 89-96. https://doi.org/e-issn 1833-8119

Meyliana, A. H., \& Budiardjo, E. K. (2016). The critical success factors for customer relationship management implementation: A systematic literature review. International Journal of Business Information Systems, 23(2), 131174. https://doi.org/10.1504/IJBIS.2016.078904

Mishra, A. N., Anderson, C., Angst, C. M., \& Agarwal, R. (2012). Electronic health records assimilation and physician identity evolution: An identity theory perspective. Information Systems Research, 23(3-part-1), 738760. https://doi.org/10.1287/isre.1110.0407

Mohamad, S. H., Othman, N. A., Jabar, J., Majid, I. A., \& Kamarudin, M. F. (2014). The impact of customer relationship management on small and medium enterprises performance. The Journal of Technology Management and Technopreneurship (JTMT), 2(2), 11-26. Retrieved from http://journal.utem.edu.my/index.php/jtmt/article/download/242/158

Mohammed, A. A., Rashid, B. B., \& Tahir, S. B. (2017). Customer relationship management and hotel performance: The mediating influence of marketing capabilities - Evidence from the Malaysian hotel industry. Information Technology \& Tourism, 17(3), 335-361. https://doi.org/10.1007/s40558-017-0085-4

Mukred, A., Singh, D. S. V., \& Safie, N. S. M. (2013). A review on the impact of information culture on the adoption of health information system in developing countries. Journal of Computer Science, 9(1), 128-138. https://doi.org/10.3844/jcssp.2013.128.138

Mukred, M., \& Yusof, Z. M. (2017, April). The DeLone-McLean information system success model for electronic records management system adoption in higher professional education institutions of Yemen. In International Conference of Reliable Information and Communication Technology (pp. 812-823). Springer, Cham. https://doi.org/10.1007/978-3-319-59427-9

Mukred, M., Yusof, Z. M., Mokhtar, U. A., \& Fauzi, F. (2018). Taxonomic framework for factors influencing ERMS adoption in organisations of higher professional education. Journal of Information Science, 45(2), 139155. https://doi.org/10.1177/0165551518783133

Ncube, F., \& Jerie, S. (2012). Leveraging employee engagement for competitive advantage in the hospitality industry. A comparative study of hotels A and B in Zimbabwe. Journal of Emerging Trends in Economics and Management Sciences, 3(4), 380-388. Retrieved from https://www.ingentaconnect.com/content/sabinet/sljetems/2012/00000003/00000004/art00013

Newby, M., Nguyen, T. H., \& Waring, T. S. (2014). Understanding customer relationship management technology adoption in small and medium-sized enterprises: An empirical study in the USA. Journal of Enterprise Information Management, 27(5), 541-560. https://doi.org/10.1108/JEIM-11-2012-0078

Ngah, A. H., Zainuddin, Y., \& Thurasamy, R. (2014). Barriers and enablers in adopting Halal transportation services: A study of Malaysian Halal Manufacturers. International Journal of Business and Management, 2(2), 4970. Retrieved from https://www.iises.net/download/Soubory/soubory-puvodni/pp-4970 ijobmV2N2.pdf

Ngah, A. H., Zainuddin, Y., \& Thurasamy, R. (2017). Applying the TOE framework in the Halal warehouse adoption study. Journal of Islamic Accounting and Business Research, 8(2), 161-181. https://doi.org/10.1108/JIABR-04-2014-0014

Nguyen, T. H., \& Waring, T. S. (2013). The adoption of customer relationship management (CRM) technology in SMEs: An empirical study. Journal of Small Business and Enterprise Development, 20(4), 824-848. https://doi.org/10.1108/JSBED-01-2012-0013

Oliveira, T., \& Martins, M. F. (2010). Understanding e-business adoption across industries in European countries. Industrial Management \& Data Systems, 110(9), 1337-1354. https://doi.org/10.1108/02635571011087428

Oliveira, T., \& Martins, M. F. (2011). Literature review of information technology adoption models at firm level. Electronic Journal of Information Systems Evaluation, 14(1), 110-121. Retrieved from http://www.ejise.com/volume14/issue1/p110

Oliver, G. (2011). Organisational culture for information managers. Chandos Information Professional Series. Elsevier. https://doi.org/10.1533/9781780632759 
Orna, E. (2008). Information policies: Yesterday, today, tomorrow. Journal of Information Science, 34(4), 547-565. https://doi.org/10.1177/0165551508092256

Osubor, V. O., \& Chiemeke, S. C. (2015). The impacts of information culture on e-learning innovation adoption in learning institutions in Nigeria. African Journal of Computing and ICT, 8(1), 17-26. Retrieved from https://pdfs.semanticscholar.org/159f/3580fce011236765f7e9f02ba2c4e87c42e5.pdf

Peltier, J. W., Zahay, D., \& Lehmann, D. R. (2013). Organizational learning and CRM success: A model for linking organizational practices, customer data quality, and performance. Journal of Interactive Marketing, 27(1), 113. https://doi.org/10.1016/j.intmar.2012.05.001

Piaralal, S. K., Nair, S. R., Yahya, N., \& Karim, J. A. (2015). An integrated model of the likelihood and extent of adoption of green practices in small and medium sized logistics firms. American Journal of Economics, 5(2), 251-258. Retrieved from http://article.sapub.org/10.5923.c.economics.201501.32.html

The Portland Trust (2012). The ICT sector in the Palestinian territory. Retrieved from https://portlandtrust.org/sites/default/files/pubs/ict special aug 2012.pdf

Qashou, A., \& Saleh, Y. (2018). E-marketing implementation in small and medium-sized restaurants in Palestine. Arab Economic and Business Journal, 13(2), 93-110. https://doi.org/10.1016/j.aebj.2018.07.001

Ragu-Nathan, B. S., Apigian, C. H., Ragu-Nathan, T. S., \& Tu, Q. (2004). A path analytic study of the effect of top management support for information systems performance. Omega, 32(6), 459-471. https://doi.org/10.1016/j.omega.2004.03.001

Rahimi, R., \& Kozak, M. (2017). Impact of customer relationship management on customer satisfaction: The case of a budget hotel chain. Journal of Travel \& Tourism Marketing, 34(1), 40-51. https://doi.org/10.1080/10548408.2015.1130108

Ramadan, H. I. M., \& Ahmad, S. (2018a). The impact of business environment on performance of manufacturing SMEs in Palestine: The empirical evidence. Asian Journal of Multidisciplinary Studies, 6(2), 1-6. Retrieved from http://www.ajms.co.in/sites/ajms2015/index.php/ajms/article/view/2903

Ramadan, H. I. M., \& Ahmad, S. (2018b). The moderating effect of environment uncertainty on the relationship between distinctive capabilities and performance of manufacturing SMEs in Palestine: A conceptual framework. International Journal of Business Marketing and Management (IJBMM), 3(2), 47-51. Retrieved from http://www.ijbmm.com/paper/Fab2018/30512487.pdf

Ramaseshan, B., Bejou, D., Jain, S. C., Mason, C., \& Pancras, J. (2006). Issues and perspectives in global customer relationship management. Journal of Service Research, 9(2), 195-207. https://doi.org/10.1177/1094670506293574

Ramayah, T., Ling, N. S., Taghizadeh, S. K., \& Rahman, S. A. (2016). Factors influencing SMEs website continuance intention in Malaysia. Telematics and Informatics, 33(1), 150-164. https://doi.org/10.1016/i.tele.2015.06.007

Raut, R. D., Gardas, B. B., Jha, M. K., \& Priyadarshinee, P. (2017). Examining the critical success factors of cloud computing adoption in the MSMEs by using ISM model. The Journal of High Technology Management Research, 28(2), 125-141. https://doi.org/10.1016/j.hitech.2017.10.004

Riyaz, A. (2009). The information culture of the Maldives: An exploratory study of information provision and access in a small island developing state. Doctoral Dissertation. Bentley, Western Australia: Curtin University of Technology. Retrieved from https://espace.curtin.edu.au/bitstream/handle/20.500.11937/2149/133399 Riyaz\%20A\%202009\%20Full .pdf

Rodriguez, M., Peterson, R. M., \& Krishnan, V. (2018). Impact of CRM technology on sales process behaviors: Empirical results from US, Europe, and Asia. Journal of Business-to-Business Marketing, 25(1), 1-10. https://doi.org/10.1080/1051712X.2018.1424754

Rogers, E. M. (2003). Diffusion of innovations (5th ed.). New York: Free Press.

Saedi, A., \& Iahad, N. A. (2013, June). An integrated theoretical framework for cloud computing adoption by small and medium-sized enterprises. In Proceedings of the Pacific Asia Conference on Information Systems (PACIS) (p. 48). Retrieved from http://aisel.aisnet.org/pacis2013/48 
CRM Initiative among Palestinian Enterprises

Salah, O. H., Yusof, Z. M., \& Mohamed, H. (2018a). A conceptual framework of CRM adoption among Palestinian SMES. Journal of Theoretical and Applied Information Technology, 97(8), 2254-2267. Retrieved from https://ukm.pure.elsevier.com/en/publications/a-conceptual-framework-of-crm-adoption-amongpalestinian-smes

Salah, O. H., Yusof, Z. M., \& Mohamed, H. (2018b). Factors affecting customer relationship management system adoption in small and medium enterprise in Palestine. International Journal of Information System and Engineering, 6(2), 52-75. https://doi.org/10.24924/ijise/2018.11/v6.iss2/52.75

Sanjay, S., Mohapatra, S., \& Anusree M. R. (2013). Business research methods. Retrieved from https://www.researchgate.net/publication/258227256 16 Sreejesh S Moh patra S Anusree M R Business Research Methods Springer USA 2013

Saunders, M., Lewis, P., \& Thornhill, A. (2009). Research methods for business students. London: Prentice Hall

Šebjan, U., Bobek, S., \& Tominc, P. (2014). Organizational factors influencing effective use of CRM solutions. Procedia Technology, 16, 459-470. https://doi.org/10.1016/j.protcy.2014.10.113

Sekaran, U. (2009). Research methods for business (4th ed.). Hoboken. Retrieved from https://iaear.weebly.com/uploads/2/6/2/5/26257106/research methods entiree book umasekarampdf-130527124352-phpapp02.pdf

Sen, A., \& Sinha, A. P. (2011). IT alignment strategies for customer relationship management. Decision Support Systems, 51(3), 609-619. https://doi.org/10.1016/i.dss.2010.12.014

Shergill, G. S., \& Chen, Z. (2005). Web-based shopping: Consumers' attitudes towards online shopping in New Zealand. Journal of Electronic Commerce Research, 6(2), 78-94. https://doi.org/10.1039/c3lc50404b

Shraim, K., \& Crompton, H. (2015). Perceptions of using smart mobile devices in higher education teaching: A case study from Palestine. Contemporary Educational Technology, 6(4), 301-318. Retrieved from https://dergipark.org.tr/en/download/article-file/252261

Sin, K. Y., Osman, A., Salahuddin, S. N., Abdullah, S., Lim, Y. J., \& Sim, C. L. (2016). Relative advantage and competitive pressure towards implementation of e-commerce: Overview of small and medium enterprises (SMEs). Procedia Economics and Finance, 35, 434-443. https://doi.org/10.1016/S2212-5671(16)00054-X

Sin, T. K., Choy, C. S., Lin, B., \& Cyril E. U. (2009). Internet-based ICT adoption: Evidence from Malaysian SMEs. Industrial Management \& Data Systems, 109(2), 224-244. https://doi.org/10.1108/02635570910930118

Sinitsyna, A. (2014). Impact of information culture and information behaviour on information quality. Masters Thesis. Wellington, New Zealand: Victoria University of Wellington. Retrieved from http://researcharchive.vuw.ac.nz/xmlui/bitstream/handle/10063/3721/thesis.pdf

Soltani, Z., \& Navimipour, N. J. (2016). Customer relationship management mechanisms: A systematic review of the state of the art literature and recommendations for future research. Computers in Human Behavior, 61, 667-688. https://doi.org/10.1016/j.chb.2016.03.008

Soltani, Z., Zareie, B., Milani, F. S., \& Navimipour, N. J. (2018). The impact of the customer relationship management on the organization performance. The Journal of High Technology Management Research, 29(2), 237246. https://doi.org/10.1016/j.hitech.2018.10.001

Son, J. Y., Narasimhan, S., \& Riggins, F. J. (2005). Effects of relational factors and channel climate on EDI usage in the customer-supplier relationship. Journal of Management Information Systems, 22(1), 321-353. https://doi.org/10.1080/07421222.2003.11045839

Sophonthummapharn, K. (2009). The adoption of techno-relationship innovations: A framework for electronic customer relationship management. Marketing Intelligence \& Planning, 27(3), 380-412. https://doi.org/10.1108/02634500910955254

Steel, M., Dubelaar, C., \& Ewing, M. T. (2013). Developing customised CRM projects: The role of industry norms, organisational context and customer expectations on CRM implementation. Industrial Marketing Management, 42(8), 1328-1344. https://doi.org/10.1016/j.indmarman.2012.08.009 
Sultan, A., Hamza A., \& Altawalbeh, M. (2018). Roles of top management and customer orientation in enhancing the performance of customer relationship management (CRM) in the hotel industry. International Journal of Advance Research and Innovation, 6(3), 233-239. Retrieved from http://transylvanianreviewjournal.org/index.php/TR/article/view/3299

Teo, T. S., Devadoss, P., \& Pan, S. L. (2006). Towards a holistic perspective of customer relationship management (CRM) implementation: A case study of the Housing and Development Board, Singapore. Decision Support Systems, 42(3), 1613-1627. https://doi.org/10.1016/j.dss.2006.01.007

Tornatzky, L., \& Fleischer, M. (1990). The processes of technological innovation. Lexington: Lexington Books. Retreived from http://www.scirp.org/(S(lz5mqp453edsnp55rrgjct55))/reference/ReferencesPapers.aspx?ReferenceID=13 $\underline{9134}$

Trainor, K. J. (2012). Relating social media technologies to performance: A capabilities-based perspective. Journal of Personal Selling \& Sales Management, 32(3), 317-331. https://doi.org/10.2753/PSS0885-3134320303

Tung, F. C., Chang, S. C., \& Chou, C. M. (2008). An extension of trust and TAM model with IDT in the adoption of the electronic logistics information system in HIS in the medical industry. International Journal of Medical Informatics, 77(5), 324-335. https://doi.org/10.1016/j.ijmedinf.2007.06.006

Ueki, Y. (2016). Customer pressure, customer-manufacturer-supplier relationships, and quality control performance. Journal of Business Research, 69(6), 2233-2238. https://doi.org/10.1016/j.jbusres.2015.12.035

Urbach, N., \& Ahlemann, F. (2010). Structural equation modeling in information systems research using partial least squares. Journal of Information Technology Theory and Application, 11(2), 5-40.

Vakola, M., \& Rezgui, Y. (2000). Organisational learning and innovation in the construction industry. The Learning Organization, 7(4), 174-184. https://doi.org/10.1108/09696470010342324

Valmohammadi, C. (2017). Customer relationship management: Innovation and performance. International Journal of Innovation Science, 9(4), 374-395. https://doi.org/10.1108/IJIS-02-2017-0011

Vasseur, V., \& Kemp, R. (2015). The adoption of PV in the Netherlands: A statistical analysis of adoption factors. Renewable and Sustainable Energy Reviews, 41, 483-494. https://doi.org/10.1016/i.rser.2014.08.020

Venkatesh, V., \& Bala, H. (2008). Technology acceptance model 3 and a research agenda on interventions. Decision Sciences, 39(2), 273-315. https://doi.org/10.1111/j.1540-5915.2008.00192.x

Venkatesh, V., Morris, M. G., Davis, G. B., \& Davis, F. D. (2003). User acceptance of information technology: Toward a unified view. MIS Quarterly, 27(3), 425-478. https://doi.org/10.2307/30036540

Venkatesh, V., Thong, J. Y., \& Xu, X. (2016). Unified theory of acceptance and use of technology: A synthesis and the road ahead. Journal of the Association for Information Systems, 17(5), 328-376. https://doi.org/10.17705/1jais.00428

Vinzi, V. E., Chin, W. W., Henseler, J., \& Wang, H. (2010). Handbook of partial least squares: Concepts, methods and applications. Springer Handbooks of Computational Statistics Series, Volume 201. Berlin: Springer. https://doi.org/10.1007/978-3-540-32827-8

Wagner, D., \& Wagner, H. T. (2013). Online communities and dynamic capabilities: A cross-case examination of sensing, seizing, and reconfiguration. In Proceedings of the $19^{\text {th }}$ Americas Conference on Information Systems, Chicago, Illinois, US A (pp. 1-8). Retrieved from https://pdfs.semanticscholar.org/f813/d8df8bad0c49b1c521b742ed340e49fe6f37.pdf

Wang, Y. S., Li, H. T., Li, C. R., \& Zhang, D. Z. (2016). Factors affecting hotels' adoption of mobile reservation systems: A technology-organization-environment framework. Tourism Management, 53, 163-172. https://doi.org/10.1016/j.tourman.2015.09.021

Wernerfelt, B. (1984). A resource-based view of the firm. Strategic Management Journal, 5(2), 171-180. Retrieved from https://www.jstor.org/stable/pdf/2486175.pdf

Williams, M. D., Rana, N. P., \& Dwivedi, Y. K. (2015). The unified theory of acceptance and use of technology (UTAUT): A literature review. Journal of Enterprise Information Management, 28(3), 443-488.

https://doi.org/10.1108/jeim-09-2014-0088 
CRM Initiative among Palestinian Enterprises

Williams, P., Ashill, N., \& Naumann, E. (2017). Toward a contingency theory of CRM adoption. Journal of Strategic Marketing, 25(5-6), 454-474. https://doi.org/10.1080/0965254X.2016.1149211

World Bank. (2018, April 16). Palestine's economic outlook. Retrieved from http://www.worldbank.org/en/country/westbankandgaza/publication/economic-outlook-april-2018

Wu, I. L., \& Wu, K. W. (2005). A hybrid technology acceptance approach for exploring e-CRM adoption in organizations. Behaviour \& Information Technology, 24(4), 303-316. https://doi.org/10.1080/0144929042000320027

Yoo, Y., \& Alavi, M. (2001). Media and group cohesion: Relative influences on social presence, task participation, and group consensus. MIS Quarterly, 25(3), 371-390. https://doi.org/10.2307/3250922

Zerbino, P., Aloini, D., Dulmin, R., \& Mininno, V. (2018). Big Data-enabled customer relationship management: A holistic approach. Information Processing \& Management, 54(5), 818-846. https://doi.org/10.1016/j.ipm.2017.10.005

Zeynep A. U., \& Toker, A. (2012). The effect of customer relationship management adoption in business-tobusiness markets. Journal of Business \& Industrial Marketing, 27(6), 497-507.

https://doi.org/10.1108/08858621211251497

\section{BIOGRAPHIES}
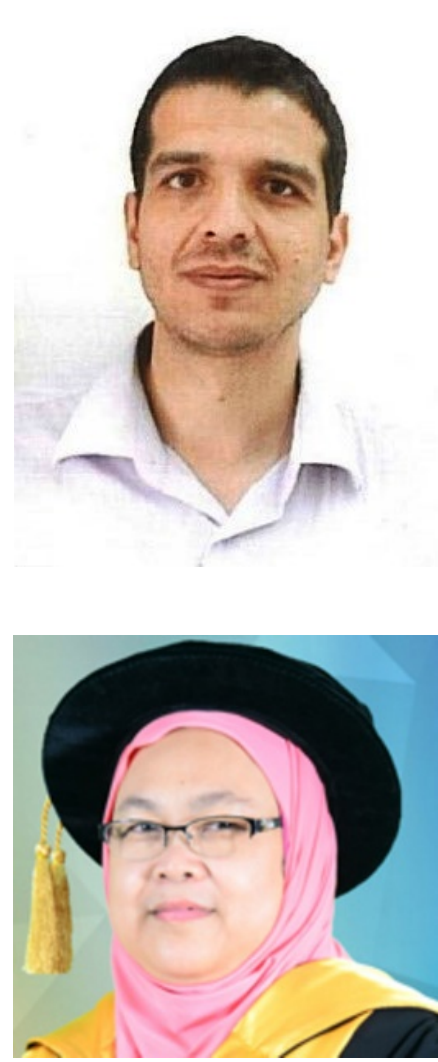

Omar Hasan Salah is a PhD student in Information Science and Technology Department at the Universiti Kebangsaan, Malaysia. He received his master's degree in management information system from University of North Texas, USA. His research interests contain Information Systems and technology innovation. His research has been published in journals including Journal of Theoretical and Applied Information Technology and International Journal of Information System and Engineering.

and technical committee for Records Management (Malaysia). She co-authored Issues in Records Management book with Robert W. Chell from West Glamorgan Archives and is ahead of Information Governance Laboratory at her faculty. Zawiyah has been invited as keynote and guest speaker at international level and has also handled short courses to corporate and government institutions locally in records management. She has delivered her inaugural speech at her university in 2015 on topic Pengurusan Rekod dan Maklumat: Isu dan Cabaran (Records and Information Management: Issues and Challenges). Prof. Zawiyah has been featured in Malaysia Who's Who in the Civil Service: 
The Steel Backbone of the Government - Crème De La Crème, p:1272, 2016; in Who's Who in the World. 31st edition. New Jersey: Marquis Whos'Who ${ }^{\circledR}$ Publication, 2014, p:1699; and Outstanding 2000 Intellectual of the 21 st Century 8th edition. St Thomas' Place: International Biographical Centre, 2014.

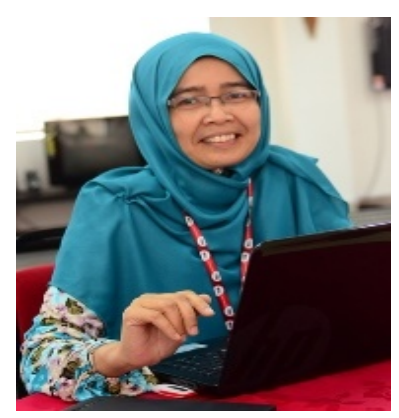

Hazura Mohamed is a senior lecturer at the Center for Software Technology and Management, Faculty of Information Science and Technology, Universiti Kebangsaan Malaysia. She obtained her $\mathrm{PhD}$ in Mathematics from Universiti Teknologi Malaysia, Malaysia.Her field of expertise is service quality, exploratory data analysis and quality model. 